Review

\title{
Superparamagnetic Iron Oxide Nanoparticles as MRI contrast agents for Non-invasive Stem Cell Labeling and Tracking
}

\author{
Li Li, Wen Jiang, Kui Luo, Hongmei Song, Fang Lan, Yao Wu ${ }^{\bowtie}$ and Zhongwei Gu ${ }^{凶}$ \\ National Engineering Research Center for Biomaterials, Sichuan University, 29 Wangjiang Road, Chengdu 610064, Sichuan, China.
}

\begin{abstract}
$\triangle$ Corresponding author: Zhongwei Gu, National Engineering Research Center for Biomaterials, Sichuan University, No. 29, Wangjiang Road, Chengdu, Sichuan, 610064, P.R.China. Tel.: +86-28-85410336 Fax: +86-28-85410653 E-mail: zwgu@scu.edu.cn Yao Wu, National Engineering Research Center for Biomaterials, Sichuan University, No. 29, Wangjiang Road, Chengdu, Sichuan, 610064, P.R.China. Tel.: +86-28-85460576 Fax: +86-28-85410653 E-mail: wuyao@scu.edu.cn.

(C) Ivyspring International Publisher. This is an open-access article distributed under the terms of the Creative Commons License (http://creativecommons.org/ licenses/by-nc-nd/3.0/). Reproduction is permitted for personal, noncommercial use, provided that the article is in whole, unmodified, and properly cited.
\end{abstract}

Received: 2012.10.10; Accepted: 2012.12.12; Published: 2013.07.31

\begin{abstract}
Stem cells hold great promise for the treatment of multiple human diseases and disorders. Tracking and monitoring of stem cells in vivo after transplantation can supply important information for determining the efficacy of stem cell therapy. Magnetic resonance imaging (MRI) combined with contrast agents is believed to be the most effective and safest non-invasive technique for stem cell tracking in living bodies. Commercial superparamagnetic iron oxide nanoparticles (SPIONs) in the aid of transfection agents (TAs) have been applied to labeling stem cells. However, owing to the potential toxicity of TAs, more attentions have been paid to develop novel SPIONs with specific surface coating or functional moieties which facilitate effective cell internalization in the absence of TAs. This review aims to summarize the recent progress in the design and preparation of SPIONs as cellular MRI probes, to discuss their applications and current problems facing in stem cell labeling and tracking, and to offer perspectives and solutions for the future development of SPIONs in this field.
\end{abstract}

Key words: stem cells, superparamagnetic iron oxide nanoparticles, labeling, tracking, magnetic resonance imaging.

\section{Introduction}

Stem cells are biological cells found in all multicellular organisms, which possess the capability of self-renewal and differentiation into various cell lineages. Until now, stem cells have been applied to not only cell-based therapies, for example, the treatment of ischaemic [1], degenerative [2], immune [3] and genetic diseases [4], but also regenerative medicine, such as the repair or regeneration of damaged heart [5], cartilage [6, 7] and bone tissue [8]. Accordingly, the tracking and monitoring of these stem cells after delivery into human body is very important for a comprehensive understanding of their proliferation dynamics, differentiation process and migration dy- namics in vivo. Currently, several imaging methodologies have been applied for this purpose, including positron emission tomography (PET) [9-11], single photon emission computed tomography (SPECT) [12], bioluminescence imaging (BLI) $[13,14]$, fluorescence imaging [15-21], X-ray based computed tomography (CT) [22] and magnetic resonance imaging (MRI) [5, 23-27]. Among them, MRI shows advantages over the others owing to its high spatial resolution $(\sim 100 \mu \mathrm{m})$, long effective imaging window, rapid in vivo acquisition of images, and the absence of exposure to ionizing radiation [28-31]. It has shown promising future in tracing cells in vivo. However, the sensitivity of MRI is generally lower as compared to SPECT and bioluminescence. Thus, the development of MRI contrast 
agents with high efficiency and sensitivity becomes essential to allowing successful bio-imaging at the cellular and molecular level.

The MRI contrast agents in clinic are divided into two parts, including $T_{1}$ and $T_{2}$ agents. Some of them in the commercial market are shown in Table $1 . T_{1}$ agents, such as paramagnetic metal lanthanide, can alter the longitudinal $\left(T_{1}\right)$ relaxation times of water protons to produce bright positive signal intensity in images and increase the conspicuousness of cells. Initially, chelate complexes of gadolinium $\left(\mathrm{Gd}^{3+}\right)$, such as the clinical contrast agent gadolinium diethylene-trianmine pentaacetic acid (Gd-DTPA) with the aid of transfection agents (TAs), were employed to label stem cells [32-34]. Recently, $\mathrm{Gd}^{3+}$ containing particles and macromolecules have been developed as a new generation of $T_{1}$ contrast agents [31, 35-39]. $\mathrm{Gd}^{3+}$-hexanedione NPs (GdH-NPs) produced stronger signal intensity than Gd-DTPA, probably because the larger Gd complexes with high molecular weight in GdH-NPs caused the slow tumbling rate of GdH-NPs [35]. $\mathrm{Gd}^{3+}$-ion clusters within ultra-short single-walled carbon nanotubes $\left(\mathrm{Gd}^{3+}{ }_{\mathrm{n}}\right.$ @US-tubes) exhibited a $T_{1}$ relaxivity $\left(r_{1}\right) 40$-fold greater than that of Gd-DTPA. It shortened relaxation time of water in labeled pig mesenchymal stem cells (pMSCs) two-fold as compared to unlabeled MSCs [36]. The Gd-DTPA bearing poly(ethyleneimine) $\left(\mathrm{SiO}_{2} / \mathrm{Gd}-\mathrm{DTPA}-\mathrm{PEI}\right)$ [31] and $\mathrm{Gd}^{3+}$ conjugated peptide dendrimers [37-39] provide great possibilities to efficiently label and monitor stem cell with high cell uptake efficiency and increased $T_{1}$ relaxivity.

$T_{2}$ agent is to alter the transverse $\left(T_{2}\right)$ relaxation times of water protons. $T_{2}$ agents provide dark negative signal intensity in images and can be used to visualize stem cells grafted in organs that appear as high signal intensity (e.g. kidney or lymphoid tissues). Compared to $T_{1}$ agents, superparamagnetic iron oxide NPs (SPIONs) based $T_{2}$ agents appear to be the preferred MRI contrast agents for monitoring stem cells due to their high sensitivity and excellent biocompatibility [40]. By far, the common labeling approach for stem cell labeling and imaging is based on combining commercially available SPIONs (e.g. Feridex ${ }^{\circledR}$ and Revosit ${ }^{\circledR}$ ) with a commercially available transfection agent (TA) (e.g. Superfect ${ }^{\mathrm{TM}}$, poly(L-lysine)(PLL) [41-43], Lipofectamine ${ }^{\mathrm{TM}}[44,45]$, or protamine sulfate $[43,46-48])$. However, one of the crucial problems of this approach is the potential toxicity of TAs to living bodies [47]. For example, PLL can cause significant cell death at the concentration of $10 \mu \mathrm{g} / \mathrm{mL}$ in media [49]. Feridex ${ }^{\circledR}$-PLL complexes have been reported to inhibit the chondrogenic differentiation capacity of MSCs [50]. In addition, Feridex ${ }^{\circledR}$ and Resovist ${ }^{\circledR}$ are no longer available commercially since 2009 [29]. Therefore, extensive efforts have been devoted to the development of novel SPIONs (some of them are shown in Table 2) in the last decade, leading to a rapid progress in the field of stem cell labeling. The present review summarizes the recent information involving the design consideration and preparation of SPIONs, discusses the current status of their applications in sensitive stem cell labeling and detection, and points out the current problems and perspectives on future directions in this field.

Table I. Some commercial MRI contrast agents [5I, 52].

\begin{tabular}{|c|c|c|c|c|c|c|}
\hline Brand name & Structure & $\begin{array}{l}\text { Hydrodynam- } \\
\text { ic size }(\mathrm{nm})\end{array}$ & $\begin{array}{l}\text { Classifica- } \\
\text { tion }\end{array}$ & Target & Company & Ref. \\
\hline Magnevist ${ }^{\circledR}$ & Gd-DTPA & & $T_{1}$ agent & Extracellular & Bayer Schering (Germany) & {$[32]$} \\
\hline Omniscan $^{\circledast}$ & Gd-DTPA-BMA & & $T_{1}$ agent & Extracellular & $\begin{array}{l}\text { GE-Healthcare (U.S.A) and Ny- } \\
\text { comed (Norway) }\end{array}$ & $\begin{array}{l}{[35,} \\
40]\end{array}$ \\
\hline Eovist $^{\circledR}$ & Gd-EOB-DTPA, Gadoxetate & & $T_{1}$ agent & Extracellular & Bayer Schering (Germany) & [51] \\
\hline $\begin{array}{l}\text { Ferumoxides } \\
\left(\text { Feridex } \mathrm{IV}^{\circledR}, \text { En- }\right. \\
\text { dorem }^{\mathrm{TM}} \text { ) }\end{array}$ & Dextran-coated SPIOs & $80-150 \mathrm{~nm}$ & $T_{2}$ agent & $\begin{array}{l}\text { Reticuloendo- } \\
\text { thelial system, } \\
\text { Liver } \\
\text { Stem cell label- } \\
\text { ing }\end{array}$ & Advanced Magnetics (U.S.A) & $\begin{array}{l}{[46,} \\
53-5 \\
5]\end{array}$ \\
\hline Resovist $^{\circledR}$ & $\begin{array}{l}\text { Carboxydextran-coated USPI- } \\
\text { Os }^{\mathrm{a}}\end{array}$ & $20 \mathrm{~nm}$ & $T_{2}$ agent & $\begin{array}{l}\text { Blood pool } \\
\text { Stem cell label- } \\
\text { ing }\end{array}$ & Bayer Schering (Germany) & $\begin{array}{l}{[45,} \\
54]\end{array}$ \\
\hline $\begin{array}{l}\text { Sinerem }^{\circledR} \\
\text { (AMI-227) }\end{array}$ & Dextran-coated USPIOs & $15-30 \mathrm{~nm}$ & $T_{2}$ agent & Blood pool & Guerbet (France) & [56] \\
\hline Ferumoxytol $^{\circledR}$ & $\begin{array}{l}\text { Carboxylmethyl-dextran } \\
\text { coated USPIOs }\end{array}$ & $30 \mathrm{~nm}$ & $T_{2}$ agent & $\begin{array}{l}\text { Macrophage } \\
\text { Blood pool }\end{array}$ & Advanced Magnetics (U.S.A) & [57] \\
\hline Ferumoxsil $^{\circledR}$ & Silicon-coated SPIOs & $300 \mathrm{~nm}$ & $T_{2}$ agent & Liver & $\begin{array}{l}\text { Guerbet, Advanced } \\
\text { Magnetics }\end{array}$ & {$[58]$} \\
\hline $\begin{array}{l}\text { Ferucarbotran }^{\circledR} \\
\text { (SHU-555A) }\end{array}$ & $\begin{array}{l}\text { Carboxydextran-coated USPI- } \\
\text { Os }\end{array}$ & $60 \mathrm{~nm}$ & $T_{2}$ agent & Liver & Bayer Schering (Germany) & [59] \\
\hline
\end{tabular}




\begin{tabular}{|c|c|c|c|c|c|c|}
\hline $\begin{array}{l}\text { Feruglose } \\
\text { NC100150 }\end{array}$ & $\begin{array}{l}\text { Pegylated starch-coated US- } \\
\text { PIOs }\end{array}$ & $20 \mathrm{~nm}$ & $T_{2}$ agent & Blood pool & GE-Healthcare (U.S.A) & [60] \\
\hline Banges $^{\circledR}$ & $\begin{array}{l}\text { SPIONs encapsulated in } \\
\text { polystyrene/divinylbenzene }\end{array}$ & $0.69-1.73 \mu \mathrm{m}$ & $T_{2}$ agent & Cell labeling & Bangs Laboratories (India) & [61] \\
\hline
\end{tabular}

Table 2. Some novel SPIONs as MRI contrast agents in stem cell labeling and tracking.

\begin{tabular}{|c|c|c|c|c|c|c|c|c|c|c|c|c|}
\hline Name & $\begin{array}{l}\text { Mag- } \\
\text { netic } \\
\text { core }\end{array}$ & Surface & $\begin{array}{l}\text { Core } \\
\text { diam- } \\
\text { eter } \\
(\mathrm{nm})\end{array}$ & $\begin{array}{l}\text { Over- } \\
\text { all size } \\
(\mathrm{nm})\end{array}$ & $\begin{array}{l}\text { Zeta } \\
\text { Poten- } \\
\text { tial } \\
(\mathrm{mV})\end{array}$ & $\begin{array}{l}\text { Mag- } \\
\text { netiza- } \\
\text { tion/ } \\
\text { emu g-1 }\end{array}$ & $\begin{array}{l}\text { Relaxiv- } \\
\text { ity/ } \\
\text { mM}^{-1} \mathbf{s}^{-1} \\
\left(\gamma_{2}\right)\end{array}$ & $\mathbf{B}_{0} \mathrm{a} / \mathrm{T}$ & $\begin{array}{l}\text { Fe/cell } \\
\text { (pg) }\end{array}$ & In vitro & In vivo & Ref \\
\hline $\mathrm{Fe}_{2} \mathrm{O}_{3}-\mathrm{PLL}$ & $\gamma-\mathrm{Fe}_{2} \mathrm{O}_{3}$ & PLL & & $6.2^{b}$ & -42 & & 213 & 1.5 & 41.5 & $\begin{array}{l}\text { Rat MSCs } \\
\text { Human MSCs } \\
\text { Human um- } \\
\text { bilical cord } \\
\text { blood MSCs }\end{array}$ & Rat brain & $\begin{array}{l}{[62-} \\
64]\end{array}$ \\
\hline $\begin{array}{l}\text { N-dodecyl-PEI2 } \\
\text { k/SPIO }\end{array}$ & $\mathrm{Fe}_{3} \mathrm{O}_{4}$ & $\begin{array}{l}\text { N-dodecyl-grafted } \\
\text { PEI } 2 \mathrm{~K}\end{array}$ & & $54.7^{b}$ & +40 & & 345 & 3 & 7.1 & Mouse MSC & $\begin{array}{l}\text { Mice } \\
\text { subcuta- } \\
\text { neous }\end{array}$ & [65] \\
\hline $\begin{array}{l}\text { iron ox- } \\
\text { ide-loaded cati- } \\
\text { onic nanovesicle }\end{array}$ & $\mathrm{Fe}_{3} \mathrm{O}_{4}$ & $\begin{array}{l}\text { (1)PEI-SA } \\
\text { (2)PEG-PGA }\end{array}$ & 6 & $150^{\mathrm{d}}$ & +20 & & 343.1 & 1.5 & 50.02 & Rat MSCs & Rat brain & [66] \\
\hline CMCS-SPIONs & $\mathrm{Fe}_{3} \mathrm{O}_{4}$ & $\begin{array}{l}\text { (Carboxyme- } \\
\text { thyl)chitosan }\end{array}$ & $6-10$ & $55.4^{\mathrm{d}}$ & -21.4 & 41.6 & 160.5 & 1.5 & 26.7 & Human MSCs & & [67] \\
\hline $\begin{array}{l}\text { ED-Pullulan } \\
\text { coating SPIO }\end{array}$ & $\mathrm{Fe}_{3} \mathrm{O}_{4}$ & $\begin{array}{l}\text { Ethylenediamine } \\
\text { Pullulan }\end{array}$ & & $94^{\mathrm{d}}$ & +10 & & & & 65 & Rat MSCs & & [68] \\
\hline UFH-SPIOs & $\mathrm{Fe}_{3} \mathrm{O}_{4}$ & $\begin{array}{l}\text { Unfractionated } \\
\text { heparin }\end{array}$ & & $50-150 c$ & & & & & 4.93 & Human MSCs & $\begin{array}{l}\text { Nude } \\
\text { mice } \\
\text { kidney }\end{array}$ & [69] \\
\hline IONP-6PEG-HA & $\mathrm{Fe}_{3} \mathrm{O}_{4}$ & $\begin{array}{l}\text { Amine-functionali } \\
\text { zd six-armed PEG } \\
\text { covalently linked } \\
\text { to hyaluronic acid }\end{array}$ & 10 & $75^{\mathrm{d}}$ & -9.1 & 79 & 454.5 & 3 & $\begin{array}{l}145.9 \mathrm{ng} \\
\mathrm{Fe} / 10^{5} \\
\text { cells }\end{array}$ & Human MSCs & & [70] \\
\hline TMA-SPIONs & $\mathrm{Fe}_{3} \mathrm{O}_{4}$ & $\begin{array}{l}\text { Polyacrylic acid } \\
\text { modified by } \\
\text { 2-aminoethyl-trim } \\
\text { ethyl ammonium }\end{array}$ & & $101^{\mathrm{d}}$ & +40 & 44.9 & 728.23 & 7 & & Human MSCs & $\begin{array}{l}\text { Mice } \\
\text { brain }\end{array}$ & [71] \\
\hline $\begin{array}{l}\text { PDMAAm-coate } \\
\text { d } \gamma-\mathrm{Fe}_{2} \mathrm{O}_{3} \mathrm{NPs}\end{array}$ & $\gamma-\mathrm{Fe}_{2} \mathrm{O}_{3}$ & PDMAAm & & $77.8^{\mathrm{d}}$ & & & 27.26 & 0.5 & 36.9 & Human MSCs & & [72] \\
\hline $\begin{array}{l}\text { FITC-PLMA-MN } \\
\text { Ps }\end{array}$ & $\mathrm{Fe}_{3} \mathrm{O}_{4}$ & FITC-PLMA & & $100^{d}$ & -34.5 & & 164.8 & & 32.7 & Human MSCs & & [20] \\
\hline $\begin{array}{l}\text { Magnetic PLGA } \\
\text { MPs }\end{array}$ & $\mathrm{Fe}_{3} \mathrm{O}_{4}$ & $\begin{array}{l}\text { PLGA(carboxyl } \\
\text { end-group) }\end{array}$ & 10 & $\begin{array}{l}0.4-3 \\
\mu \mathrm{m}\end{array}$ & & 40 & 316.7 & & 80 & Mouse MSCs & $\begin{array}{l}\text { BALB/C } \\
\text { mice } \\
\text { back and } \\
\text { ears }\end{array}$ & [73] \\
\hline Citrate SPION & $\mathrm{Fe}_{3} \mathrm{O}_{4}$ & Citrate & $6-7$ & $90.13^{d}$ & -27.3 & & & 7 & 69.6 & Human MSC & $\begin{array}{l}\text { Mice } \\
\text { muscle }\end{array}$ & [74] \\
\hline $\begin{array}{l}\text { D-mannose } \\
\text { coated SPIONs }\end{array}$ & $\gamma-\mathrm{Fe}_{2} \mathrm{O}_{3}$ & D-mannose & & $6^{\mathrm{b}}$ & & & 140.4 & 0.5 & 51.7 & Rat MSCs & & $\begin{array}{l}{[64,} \\
75]\end{array}$ \\
\hline $\mathrm{SPIO} @ \mathrm{SiO}_{2}-\mathrm{NH}_{2}$ & $\mathrm{Fe}_{3} \mathrm{O}_{4}$ & $\mathrm{SiO}_{2}-\mathrm{NH}_{2}$ & 6 & $8.5^{b}$ & & 52.5 & 43.5 & 3 & 68.7 & Rabbit MSCs & $\begin{array}{l}\text { Rabbits } \\
\text { brain }\end{array}$ & [76] \\
\hline $\begin{array}{l}\mathrm{MNPs} @ \mathrm{SiO}_{2}(\mathrm{RIT} \\
\mathrm{C} \text { or FITC) }\end{array}$ & $\mathrm{Fe}_{3} \mathrm{O}_{4}$ & $\begin{array}{l}\mathrm{SiO}_{2} \text { containing } \\
\text { RITC or FITC }\end{array}$ & 9 & $30-80 \mathrm{~b}$ & & & & 1.5 & & Human MSC & $\begin{array}{l}\text { NOD-SCI } \\
\text { D mice }\end{array}$ & $\begin{array}{l}{[77-} \\
79]\end{array}$ \\
\hline Mag-Dye@MSNs & $\mathrm{Fe}_{3} \mathrm{O}_{4}$ & $\begin{array}{l}\mathrm{SiO}_{2} \text { and FITC- } \\
\text { incorporated } \\
\text { mesoporous silica }\end{array}$ & & & & & & 1.5 & & Human MSC & $\begin{array}{l}\text { Nude } \\
\text { mice } \\
\text { brain }\end{array}$ & [80] \\
\hline TAT-CLIO & $\mathrm{Fe}_{3} \mathrm{O}_{4}$ & $\begin{array}{l}\text { Tat peptide func- } \\
\text { tionalized } \\
\text { cross-linking dex- } \\
\text { tran }\end{array}$ & & $65.2^{\mathrm{d}}$ & & & 73.4 & 0.47 & 2.15 & Human NSCs & & $\begin{array}{l}{[53,} \\
81]\end{array}$ \\
\hline LMWP-SPIO & $\mathrm{Fe}_{3} \mathrm{O}_{4}$ & LMWP & & $26.77^{\mathrm{d}}$ & 16.97 & 85 & & & 2.3 & Human MSCs & & [82] \\
\hline
\end{tabular}

Notes: a magnetic field. $\mathrm{b}$ size determined by TEM method. c size determined by AFM method. ${ }^{\mathrm{d}}$ hydrodynamic size measured by dynamic light scattering. 


\section{Design considerations of SPIONs for stem cell labeling}

For designing SPIONs based MRI probes, there are several important aspects that need to be considered: 1) stem cell uptake, this is a necessary prerequisite for the application of SPIONs for stem cell labeling; 2) $T_{2}$ relaxivity, this is directly related to the MRI probe sensitivity; 3) a long-term stay in cells, SPIONs-labeled cells should retain the label and remain viable by MR for weeks, even months because preclinical and clinical trials mostly will need a long-term follow-up of tissue function and the fate of labeled cells; and 4) biosafety, the formulations should be biocompatible to stem cells and the host without side effects on their biological properties and functions.

NPs are carried into non-phagocytosis cells such as stem cells mainly via endocytosis path. Four basic mechanisms have been proposed by previous reports, including: macropinocytosis, clathrin- or caveolae-mediated endocytosis, and pathways that independent of clathrin and caveolae [83-85]. There are a few factors that strongly affect the endocytosis of NPs, including particle size, surface charge, surface chemistry, and cell lines $[63,86]$. Numerous reviews have described and discussed the internalization mechanism and influential factors $[30,85,87]$. On the size side, particles with the size less than $100 \mathrm{~nm}$ (hydrodynamic diameter) are generally preferred for cell uptake [68]. In the ranging from 2 to $100 \mathrm{~nm}$, it was reported that the most efficient cells uptake of herceptin conjugated colloidal gold NPs (Her-GNPs) occurred within the 25-50 nm size range [88]. In term of surface charge, positive surface charges are expected to facilitate the phagocytotic uptake as a result of electrostatic attraction between the positively charged particles and negatively charged cell membrane. Most of transfection agents which can effectively introduce exogenous gene into various cells are cationic compounds, such as cationic lipids [89, 90], polymers, dendrimers [91, 92] and NPs. Moreover, Shui group reported a clear positive correlation of surface charge of PEG-PGA/PEI-SA/SPIO NPs and labeling efficiency in rat MSCs [66]. In regard to surface chemistry, it is critical for uptake efficiency and specific cell internalization. For example, (Carboxymethyl) chitosan coated SPIONs and citrate coated SPIONs showed high efficiency in stem cell internalization due to the specific surface chemistry, despite they were negatively charged [67]. Furthermore, our group has designed and prepared hydrophilic SPIONs with glucosaminic acid (GA) coating and found that GA modified SPIONs internalized more quickly to cancer cells than to normal cells lines [93]. In addition, the cell targeting moieties on the surface of NPs, such as peptides from the human immunodeficiency virus (HIV) TAT protein and Herpes simplex virus (HSV), may mediate reporter-ligand endocytosis and efficiently enhance the internalization. Stem cells with different types (e.g. MSCs and NSCs) and different donors (e.g. pig, rabbit, rat, mouse and human) may show different internalization efficiency with the same NPs $[63,76,81]$.

Three major factors govern the $T_{2}$ relaxivity of SPION agents, including particle size, composition, and crystallinity $[96,97] . T_{2}$ relaxivity is highly sensitive to particle size and larger SPIONs generally have higher $T_{2}$ relaxivity [61]. However, superparamagnetic size limit in magnetic iron oxide is $20 \mathrm{~nm}$. Iron oxide cores with diameter beyond this limit are usually no longer superparamagnetic. Two methods have been reported to effectively maintain the superparamagnetism and enhance $T_{2}$ relaxivity of SPIONs. One is the controllable aggregation of NPs into clusters, which induces the magnetic relaxation switch effect [65, 98-101]. For example, the $T_{2}$ relaxivity of amphiphilic alkyl-PEI/SPIONs micelles (323 $\mathrm{mM}^{-1} \mathrm{~s}^{-1}$ ) with multiple SPIONs were higher than that with single SPION $\left(118 \mathrm{mM}^{-1} \mathrm{~s}^{-1}\right)$ at the magnetic field of 1.5 $\mathrm{T}$. The other method is to confine SPIONs in micrometer-sized polymer particles, for example PLGA, which can enhance molar relaxivity of the $\mathrm{Fe}$ and cellular internalization [73]. Other parameters of critical importance to the performance of NPs are the composition and the crystallinity. Lee et al [102] found that $\mathrm{MnFe}_{2} \mathrm{O}_{4}$ NPs showed the highest magnetic susceptibility and thus the strongest $T_{2}$ shortening effect among a series of metal doped iron oxide NPs of spinel $\mathrm{MFe}_{2} \mathrm{O}_{4}(\mathrm{M}=\mathrm{Mn}, \mathrm{Fe}$, Co or $\mathrm{Ni})$ at similar size. As for iron oxide NPs, Basti et al showed that the magnetite $\left(\mathrm{Fe}_{3} \mathrm{O}_{4}\right)$ provided a stronger $T_{2}$ shortening effect than the maghemite $\left(\gamma-\mathrm{Fe}_{2} \mathrm{O}_{3}\right)$ [103].

Proliferation and exocytosis are two main factors that hamper the long-retention of SPIONs in cells. When a cell proliferates, SPIONs are divided evenly or unevenly into two daughter cells. After several cycles, the label can be diluted below detectable levels. Proliferation is very likely to occur for stem and progenitor cells due to their strong self-renewal ability. Therefore, magnetic particles with high $T_{2}$ relaxivity and high iron loading are of importance for cellular MRI due to the time-dependent decrease of Fe content in cells. Furthermore, exocytosis process of stem cells also dilutes the Fe content per cell [104]. It has been reported that exocytosis is size dependent and smaller particles are exocytosed at a faster rate. 
$\mathrm{Xu}$ et al showed that the internalization of SPIONs loaded PLGA microparticles (SPIONs-PLGA MPs) in MSCs enhanced residence time inside the cells (3-fold) compared to SPIONs alone [73]. Degradability of SPIONs is another factor that affects their duration time. One successful example is the $\mathrm{SiO}_{2}$ coated SPIONs, as reported by Wang's group [76]. It had stayed in stem cells and remained visible by MRI for 8-12 weeks, probably due to the stability of $\mathrm{SiO}_{2}$ under the cellular circumstance.

For biosafety consideration, understanding the properties of NPs and their effects on the host are crucial before clinical use can occur. It is generally accepted that iron oxide is non-toxic to cells, since it can be degraded and utilized by cells via physical iron metabolism pathway [106]. However, several groups recently have reported that high Fe load in cells is toxic to cells and would interfere the normal function of stem cells [94, 95, 107, 108]. SPION toxicity is influenced by many factors including size, charge, surface chemistry, dose, and agglomeration state of NPs, etc. [105]. Given a particular type of iron oxide NPs, an appropriate coating contributes to make the SPIONs less toxic. Meanwhile, systematic studies have to be conducted to assess the potential long-term toxicity of SPIONs in vivo [97].

\section{Design strategies of SPIONs for stem cell labeling}

Hydrophilic SPIONs for biological application usually consist of an iron oxide core and a surface coating. On one hand, synthesis methods of the iron oxide core, stabilizer and reaction parameters have significant effects on the size and magnetic properties of SPIONs [52, 109-111]. On the other hand, surface coating materials, functionalization materials and surface engineering methods significantly affect ultimate size in living fluid, biocompatibility, cell internalization and duration in cells [26, 30, 112, 113]. Therefore, to prepare ideal SPIONs, major factors such as core synthesis, surface coating and functional materials, and surface engineering methods should be carefully considered.

\section{Synthesis of cores}

Chemical methods used to synthesize SPIONs mainly include coprecipitation [63, 69, 72], thermal decomposition [114], pyrolysis method [114], hydrothermal reactions [115], and sol-gel syntheses [116]. Until now, the main challenges in the synthesis of iron oxide core are (i) mono-dispersibility with required size, (ii) good magnetic properties. The two most extensively used methods in preparation of SPIONs for stem cells are coprecipitation and thermal decomposition technique. The following section summarizes the properties and applicability of both methods and provides a novel strategy for the synthesis of iron oxide cores.

The coprecipitation technique is probably the simplest and efficient chemical pathway to obtain SPIONs (either $\mathrm{Fe}_{3} \mathrm{O}_{4}$ or $\gamma-\mathrm{Fe}_{2} \mathrm{O}_{3}$ ). Magnetic particles are usually prepared by controlling the precipitation of iron oxides in aqueous $\mathrm{Fe}^{2+} / \mathrm{Fe}^{3+}$ salt and stabilizers through the addition of an alkaline solution in a non-oxidizing oxygen environment. The main advantage of coprecipitation process is high production of SPIONs [52]. However, the main drawback of this method is that the prepared particles tend to be poly-disperse with non-unique shape. In the coprecipitation process, two stages are involved: a short burst of nucleation and slow growth of the nuclei. Controlling size and distribution at the first stage has been reported to be very important for the preparation of monodispersed particles. The size and shape of the NPs can be controlled with relative success by selecting the type of salts (e.g. chlorides, sulfates and nitrates), and adjusting the $\mathrm{Fe}^{2+} / \mathrm{Fe}^{3+}$ concentration ratio, reaction temperature, $\mathrm{pH}$ value, ionic strength of the media and the addition of the chelating organic anions (such as citric, gluconic or oleic acid) or polymer coating materials (such as polyvinylpyrrolidone (PVP), dextran and starch) [74, 112]. The other problem is that the yielding ferrous colloid is often the mixture of $\mathrm{Fe}_{3} \mathrm{O}_{4}$ and $\gamma-\mathrm{Fe}_{2} \mathrm{O}_{3}$, and the former is not stable and subjected to oxidation into the latter in the presence of oxygen or at high temperature. In term of stem cell labeling, much more work have been carried out by using $\mathrm{Fe}_{3} \mathrm{O}_{4}$, due to its superior magnetic properties [117]. Occasionally, it was reported that the uncoated $\gamma-\mathrm{Fe}_{2} \mathrm{O}_{3}$, exhibited higher $r_{2}$ relaxivity as compared to commercially available Endorem ${ }^{\mathrm{TM}}$, Sinerem ${ }^{\circledR}$ and Resovist ${ }^{\circledR}$ [64].

Thermal decomposition of organometallic precursors, such as $\mathrm{Fe}(\mathrm{Cup})_{3}, \mathrm{Fe}(\mathrm{CO})_{5}$ or $\mathrm{Fe}(\mathrm{acac})_{3}$ in high-boiling organic solvents containing surfactants can produce monodispersed magnetic NPs. The most outstanding advantage of this method is that the prepared NPs have controllable size in a narrow distribution and high crystallinity. The ratios of the starting reagents including organometallic compounds, surfactants, and solvents are the decisive parameters for the control of the particle size. In addition, the reaction temperature, reaction time, and aging period are also important factors for the precise control of size [52]. Hyeon's group [114] has synthesized high crystalline and monodisperse $\gamma-\mathrm{Fe}_{2} \mathrm{O}_{3}$ 
nanocrystallites with size varied from $4 \mathrm{~nm}$ to $16 \mathrm{~nm}$ by controlling the experimental parameters. Sun's group [118] also synthesized monodispersed $\mathrm{MFe}_{2} \mathrm{O}_{4}$ $(\mathrm{M}=\mathrm{Fe}, \mathrm{Co}, \mathrm{Mn}) \mathrm{NPs}$ by thermal decomposition (Figure 1). Particle diameter can be tuned from 3 to 20 $\mathrm{nm}$ by varying reaction conditions or seed-mediated growth. Our group synthesized ternary SPIONs doped with $\mathrm{Mn}$ and $\mathrm{Zn}$ elements via thermal decomposition [119]. The yielding magnetic NPs had high saturation magnetization (increasing $23 \%$ as compared to that without dopants) and small particle size $(8 \mathrm{~nm})$ with a narrow size distribution. The SPIONs prepared by thermal decomposition were hydrophobic because of the coverage of hydrophobic surfactants and needed to be transformed into hydrophilic ones for further biological application.

Based on the advantages of both coprecipitation and thermal decomposition method, our group explored a novel one-pot method with sodium oleate as both the surfactant and precipitant to synthesize monodispersed SPIONs in the water/ethanol/ toluene system $[110,111,120,121]$. The convenient and mild reaction condition, high yield and narrow size distribution of the obtained SPIONs indicate this method has great potential for industry production. As shown in Figure 2, our group parepared SPIONs with a size of $8 \mathrm{~nm}$ by this simple method. This system merely required iron chlorides and sodium oleate because sodium oleate served as both an anionic surfactant and a key reactant in buffering the concentration of $\mathrm{OH}^{-}$for homogeneous SPION nucleation and crystal growth, which was quite different from the traditional preparation methods [110]. Furthermore, the composition of products from the mixture of magnetite and maghemite to pure magnetite could be adjusted by varying the iron concentration and feed ratio [111]. Similar to the thermal decomposition, the obtained hydrophobic SPIONs in our method required hydrophilic modification for biological applications.
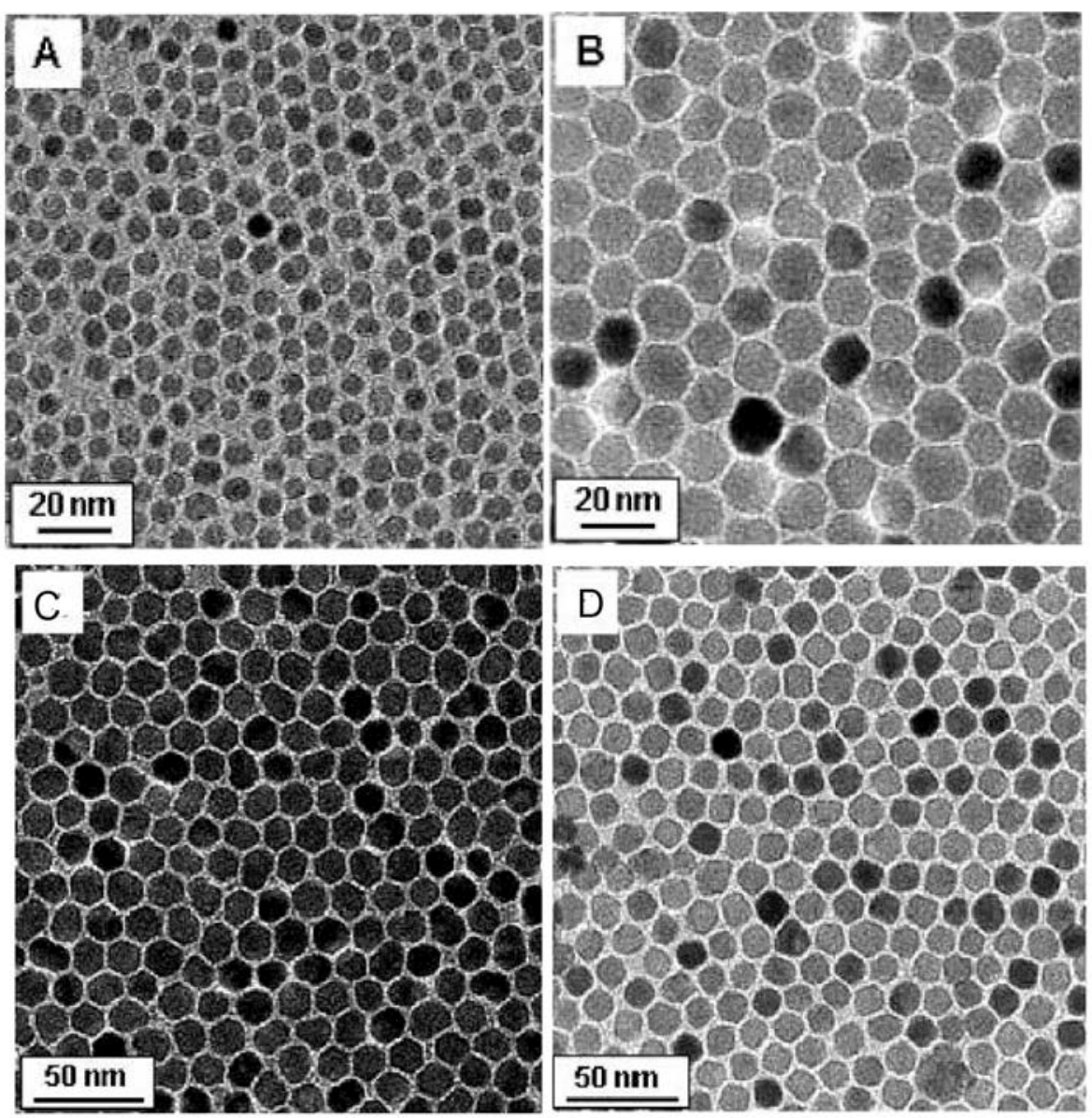

Fig I. TEM images of $\mathrm{MFe}_{2} \mathrm{O}_{4}\left(\mathrm{M}=\mathrm{Fe}, \mathrm{Co}, \mathrm{Mn}\right.$ ) prepared by thermal decomposition. (A) $6 \mathrm{~nm} \mathrm{Fe} \mathrm{O}_{4}$, (B) $12 \mathrm{~nm} \mathrm{Fe} \mathrm{O}_{3}$ (C) $14 \mathrm{~nm} \mathrm{CoFe} \mathrm{O}_{4}$ and (D) $14 \mathrm{~nm}$ $\mathrm{MnFe}_{2} \mathrm{O}_{4}$; reprinted with permission from ref. [1 I 8]. Copyright (2004) American Chemical Society. 

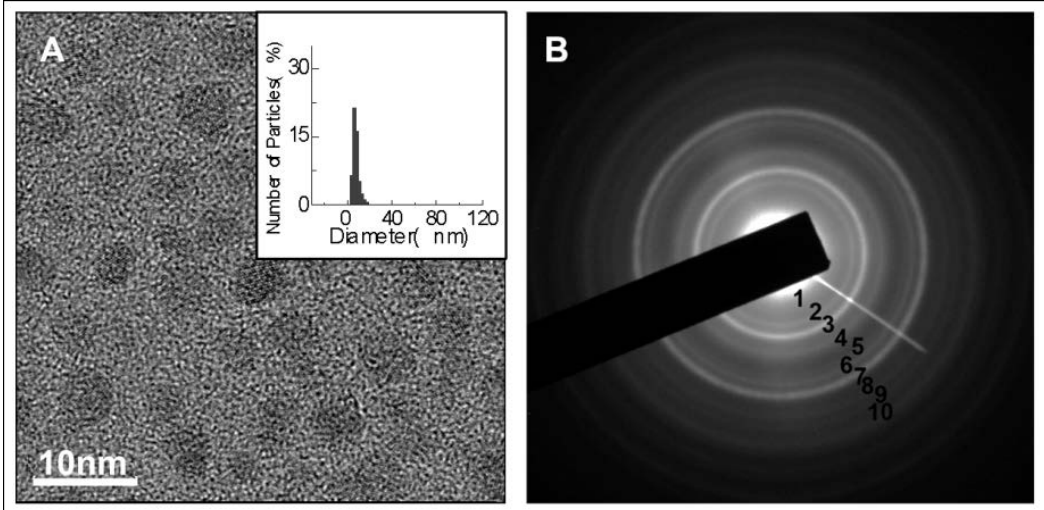

Fig 2. (A) TEM micrographs and the corresponding particle size histograms by DLS (insets) $(8 \mathrm{~nm})$ of SPIONs prepared by a novel one-pot method with sodium oleate as both the surfactant and precipitant; (B) the SAED pattern of SPIONs; reprinted with permission from ref. [I I 0] Copyright (20 I0) Elsevier.

\section{Surface modification}

Although many synthetic routes have been developed for the preparation of iron oxide core with tunable shape, size and magnetization, several challenges remain for the naked SPIONs in terms of stem cell labeling, including: (i) poor water solubility and tendency of aggregation due to large surface/volume ratio; (ii) low cellular uptake efficiency; (iii) potential toxicity. To address these problems, the most straightforward and effective method seems to be coating the iron oxide core by a layer. The nature of the surface coatings and modification methods determine the physical and biologic properties such as the overall size, surface charge, coating density, toxicity and degradability, which finally affect the fate of SPIONPs in the cells $[93,112]$. This following section focuses on the currently used surface modification materials (e.g. PLL, PEI, chitosan, PEG, citric acid and so on) and methods (e.g. in situ coating, post-synthesis coatings including blending, polymerization, ligand exchange) for the SPIONs applied for stem cell labeling and tracking. The influence of these factors on labeling efficiency and biocompatibility is also discussed.

\section{Polymers}

\section{Polycations}

Polycations are extensively used as the intracellular delivery carriers, because their positive surface charges induce them to interact with negatively charged cell membrane and facilitate internalization. Meanwhile it can be easily combined to the negatively charged SPIONs due to the electrostatic interaction.

Poly(L-lysine) (PLL), a positively charged peptide, is widely used as transfection agent for the complexation and delivery of genes [122]. It is also known to enhance the cell adhesion to the surface of culture dish during cell cultivation. PLL can coat negatively charged SPIONs such as Feridex ${ }^{\circledR}$ and chaperon them into stem cells via electrostatic interaction. The common preparation method is post-synthesis coating. Briefly, an aqueous solution of PLL is added into the fresh water-based magnetic fluid prepared through coprecipitation and the reaction is carried on with stirring to obtain PLL capped NPs [62-64]. Horák's group [63] had tested the influence of the molecular weight of PLL (ranging from $146 \mathrm{D}$ to $579 \mathrm{kD}$ ) and PLL/ $\mathrm{Fe}_{2} \mathrm{O}_{3}$ feed ratio (from 0 to 0.009 ) on the capability of PLL to increase the intracellular uptake of the NPs $\left(\mathrm{PLL}-\mathrm{Fe}_{2} \mathrm{O}_{3}\right.$ ). The maximum cell labeling efficiency (labeled rat MSCs 92.2\%) was achieved with $0.02 \mathrm{mg}$ PLL per $\mathrm{mL}$ of $\mathrm{PLL}-\mathrm{Fe}_{2} \mathrm{O}_{3}$ colloid (PLL $/ \mathrm{Y}-\mathrm{Fe}_{2} \mathrm{O}_{3}$ mass ratio of 0.009 and PLL molecular weight of $388 \mathrm{kD}$ ). The coating of the naked iron oxide with different amount of PLL (Mw $388 \mathrm{kD}$ ) did not change the morphology or the size of the core $(\sim 6 \mathrm{~nm})$ (Figure 3A and 3B). The coating force between PLL and $\gamma-\mathrm{Fe}_{2} \mathrm{O}_{3}$ was electrostatic interaction (Figure 3C). TEM examination of PLL- $\mathrm{Fe}_{2} \mathrm{O}_{3}$ showed the successful internalization into lysosomes (Figure 3D), and the mechanism of cellular uptake was supposed to be endocytosis and/or diffusion through the cell membranes. Cell labeling with PLL- $\mathrm{Fe}_{2} \mathrm{O}_{3}$ was more efficient and safer than that with a conventionally used agent (Endorem $\left.{ }^{\mathrm{TM}}\right)$. Horák's group also found that PLL- $\mathrm{Fe}_{2} \mathrm{O}_{3}$ had higher relaxivity $\left(r_{2}\right)$ value than PLL-Endorem ${ }^{\mathrm{TM}}$ complex and uncoated $\mathrm{Fe}_{2} \mathrm{O}_{3}$ [64]. Ju and coworkers [62] coated $\mathrm{Fe}_{2} \mathrm{O}_{3}$ with PLL by the similar post-synthesis as Horák's group described, but they washed the PLL- $\mathrm{Fe}_{2} \mathrm{O}_{3}$ several times to remove free PLL. Therefore, the amount of PLL adsorbed on particle surface was only $0.01 \%$ of the total $\mathrm{Fe}_{2} \mathrm{O}_{3}$ mass. Prussian blue staining results demonstrated that almost all of human umbilical cord blood mesenchymal stem cells (UCB-MSCs) had shown clear blue after the treatment with $\mathrm{PLL}-\mathrm{Fe}_{2} \mathrm{O}_{3}$ under the 
optimal Fe concentration $(20 \mu \mathrm{g} / \mathrm{mL}$ of Fe). Owing to the low PLL content, no significant toxicity of PLL- $\mathrm{Fe}_{2} \mathrm{O}_{3}$ was observed as compared to the unlabeled cells, even at a high co-incubating concentration up to $200 \mu \mathrm{g} / \mathrm{mL}$ of Fe. $T_{2}$ weighted image (WI) and
$\mathrm{T}_{2}{ }^{*} \mathrm{WI}$ demonstrated significant decrease of signal intensity in vials containing $1 \times 10^{6}$ ( 1 day and 8 days) labeled cells, in comparison with the unlabeled cells.
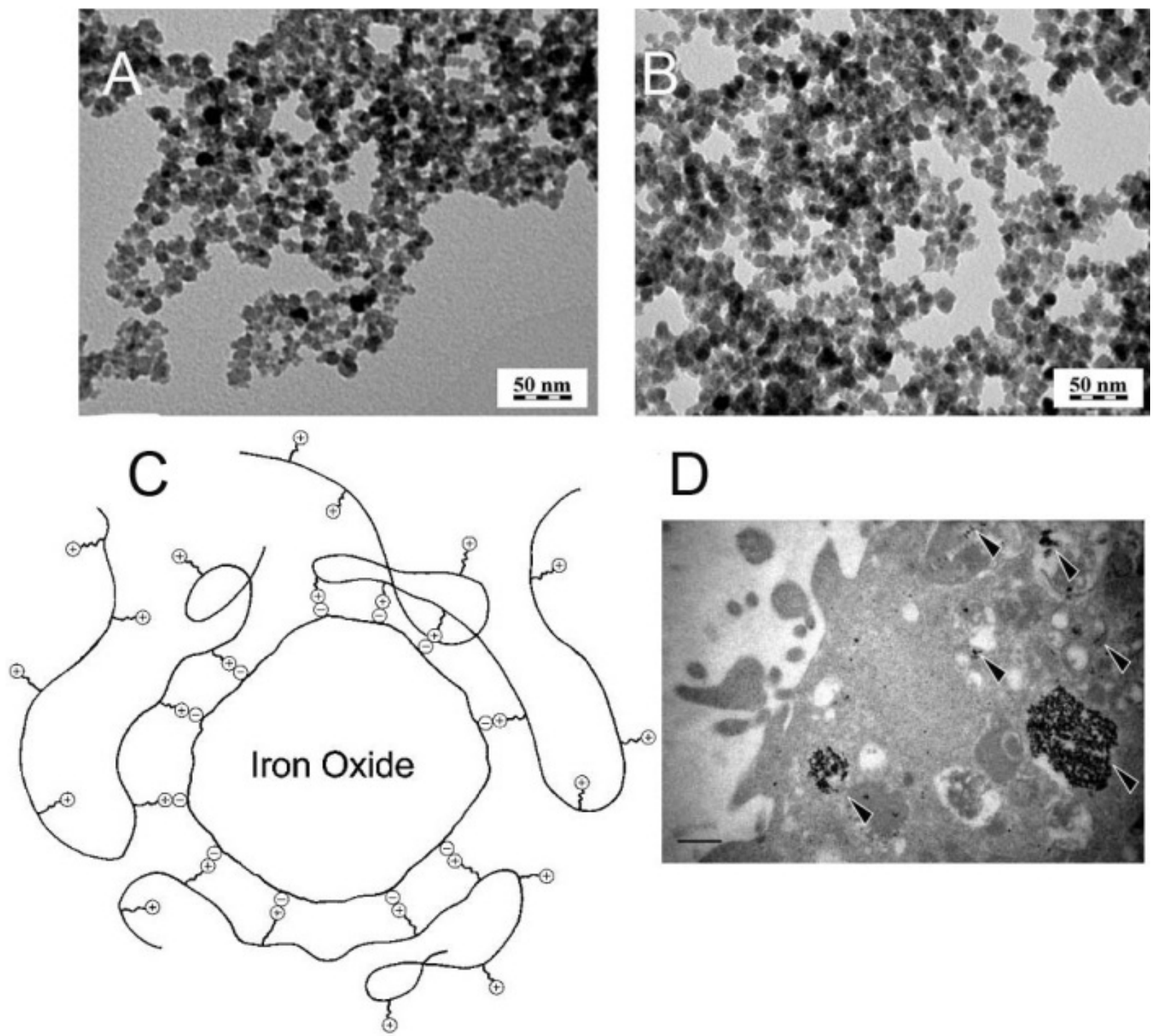

Fig 3. TEM micrographs of (A) uncoated $\gamma-\mathrm{Fe}_{2} \mathrm{O}_{3} \mathrm{NPs}$ and (B) PLL- $\mathrm{Fe}_{2} \mathrm{O}_{3}\left(\mathrm{PLL} / \mathrm{Fe}_{2} \mathrm{O}_{3}=0.009\right.$, mass ratio); (C) Schematic illustration of the interaction between PLL and a citrate-treated $\gamma-\mathrm{Fe}_{2} \mathrm{O}_{3}$; (D) TEM micrographs of $\mathrm{rMSC}$ cells labeled with $\mathrm{PLL}-\mathrm{Fe}_{2} \mathrm{O}_{3}\left(\mathrm{PLL} / \mathrm{Fe}_{2} \mathrm{O}_{3}=0.005\right)$ and scale bar I $\mu \mathrm{m}$; reprinted with permission from ref. [63]. Copyright (2008) American Chemical Society.

Polyethyleneimine (PEI), another cationic polymer with many primary amino groups, has shown relatively higher gene transfection efficiency, as compared to other non-viral vectors (e.g. PLL, DOTAP liposome), especially for PEI 25kD. It can facilitate cellular uptake and endosomal escape through an "a proton sponge effect" [123]. However, PEI also exhibits cytotoxic effect including cell death, apoptosis or inhibition of cell differentiation. Recent- ly, low molecular weight PEI as an alternative to PEI $25 \mathrm{kD}$ has drawn more and more attention, because of its improved biocompatibility. Liu and co-worker prepared amphiphilic N-dodecyl-grafted PEI 2k with a graft ratio of $11 \%[65,124]$. The hydrophobic SPIONs obtained by thermal decomposition and $\mathrm{N}$-dodecyl-grafted PEI $2 \mathrm{k}$ were dispersed in chloroform. The mixture was under shaking for overnight and the alkyl-PEI/SPIO complexes were obtained 
after evaporation of chloroform. The mass ratio of $\mathrm{N}$-alkyl-PEI2k to SPIO was a key factor of the stability, biocompatibility and relaxivity of the complex. The complex micelle with mass ratio of 0.6 could hold several SPIONs with a clustering structure (see Figure $4 \mathrm{~A}$ and $4 \mathrm{~B}$ ), leading to much higher cell labeling and $\mathrm{T}_{2}$ relaxivities $\left(345 \mathrm{mM}^{-1} \mathrm{~s}^{-1}\right)$ measured on 3T MR scanner, as compared to single SPIONs for example Endorem $^{\mathrm{TM}}$ (about $176 \mathrm{mM}^{-1} \mathrm{~s}^{-1}$ ). The incubation of MSCs with alkyl-PEI/SPIO $(7 \mu \mathrm{g} / \mathrm{mL}$ of Fe, mass ratio $=0.6$ ) for $24 \mathrm{~h}$ achieved $7.1 \mathrm{Fe} \mathrm{pg} /$ cell and labeled mice MSCs were unaffected in their viability, proliferation, or differentiation capacity. Subcutaneous injection of the labeled MSCs into BALB/c mice showed strong signal contrast against unlabeled cells under a 3T MR scanner for 19 days post-transplantation (Figure $4 \mathrm{C}$ and $4 \mathrm{D}$ ). Shuai's group [66] synthesized cationic stearic acid-grafted PEI (PEI Mw $=423 \mathrm{Da})$ co-
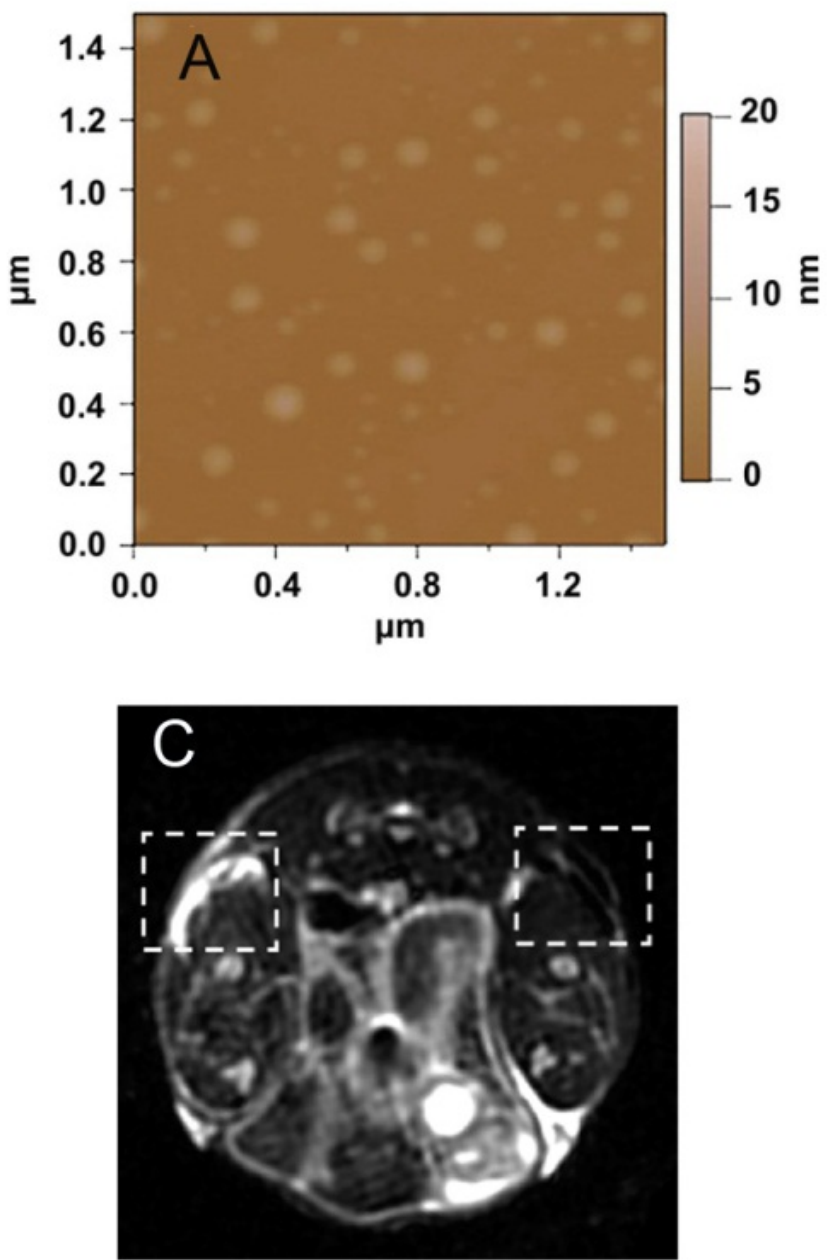

polymers (PEI-SA) and anionic poly(ethylene glycol)-poly( $\gamma$-benzyl-L-glutamate) (PEG-PBLG) $(\mathrm{Mn}=$ $9.3 \mathrm{kDa}$ ). They firstly coated hydrophobic SPIONs prepared by thermal decomposition with PEI-SA through a blending method, as described in Liu's report [65]. Subsequently, PEI-SA modified SPIONs were coated with PEG-PBLG via electrostatic interaction. The zeta potential of PEG-PBLG/PEI-SA/SPIONs could be controlled through adjusting the mass ratio of PEG-PBLG to PEI-SA. It was found that labeling efficiency increased linearly with the zeta potentials of PEG-PBLG/PEI-SA/SPIONs. Under optimal cell labeling conditions involved an iron concentration of $3.15 \mu \mathrm{g} / \mathrm{mL}$ with $20 \mathrm{mV}$ positive charge and $1 \mathrm{~h}$ incubation time, a mean iron concentration in rat MSCs reached $50.02 \mathrm{pg} / \mathrm{cell}$.
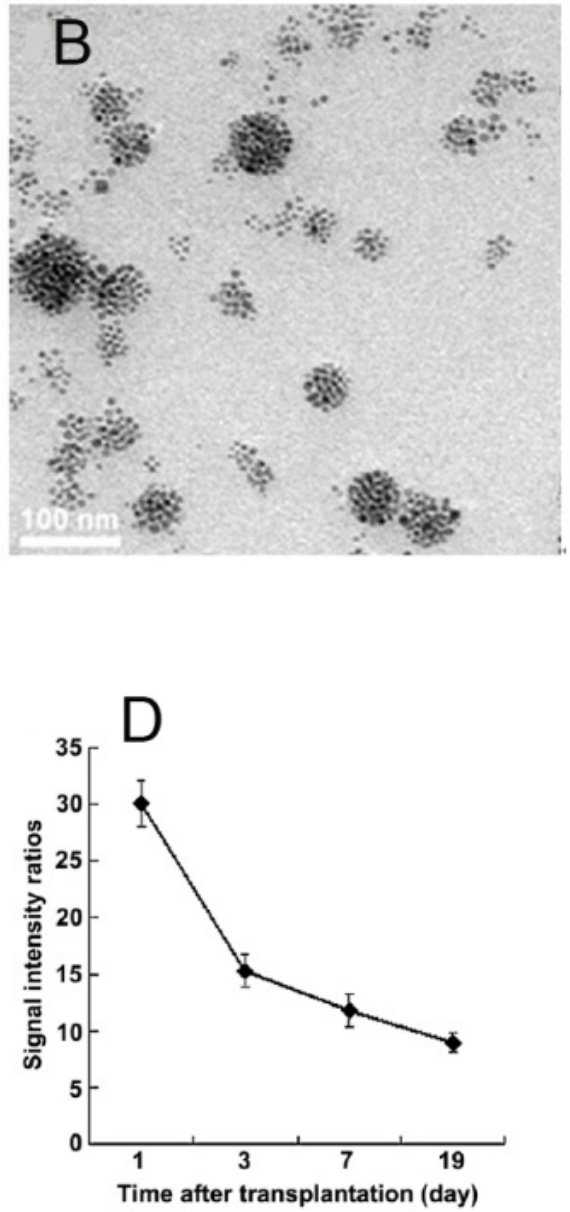

Fig 4. Characterization of SPIONs (polymer/SPIO mass ratio $=0.6$ ) and in vivo MRI of SPIO-labeled MSCs. (A) AFM height image; (B) TEM image of SPIONs nanoparticle clusters; (C) $T_{2}{ }^{*}$-weighted gradient echo image shows a prominent hypointense area of labeled injection in the right frank (19 d after transplantation); (D) the ratios of signal intensities of the control and the labeled injection; reprinted with permission from ref. [65]. Copyright (20II) Elsevier. 


\section{Polysaccharides}

Polysaccharides, especially those from natural sources, exhibit many specific properties compared to other materials, including water-solubility, biocompatibility, biodegradability, biological activity and low cost [125]. Polysaccharides enriched with hydroxyl groups have been reported to interact with iron oxide via hydrogen bonding [126]. Chitosan, pullulan, and heparin are the currently used polysaccharides for coating SPIONs.

Chitosan [poly(1,4- $\beta$-D-glucopyranosamine)], a biodegradable natural polymer, is derived by the deacetylation of chitin obtained from the shells of crustaceans. It has many biological applications because of its biological activities, biocompatibility, high charge density, low toxicity toward mammalian cells, and ability to improve dissolution. Chitosan coated SPIO (Chitosan-SPIO) NPs had the core size of $6 \mathrm{~nm}$ and hydrodynamic size of $65 \mathrm{~nm}$ including the chitosan coat, which are similar to those of Resovist ${ }^{\circledR}$ (core iron size: $4.2 \mathrm{~nm}$, total hydrodynamic size: 62 nm) [127]. Inductively coupled plasma-atomic emission spectroscopy (ICP-AES) data revealed that similar amounts of iron $(\sim 18 \mathrm{pg} / \mathrm{cell})$ was taken up by hMSC when labeled with Chitosan-SPIO or Resovist ${ }^{\circledR}$ iron particles in the presence of PLL (388 kD). However, Chitosan-SPIO alone could not efficiently label cells. The carboxymethylation of chitosan increases its water solubility, and enhances the dispersion of SPIONs in aqueous media [67]. Furthermore, carboxymethyl chitosan (CMCS) has been shown to enhance interactions with the cell membrane [128]. Shi and co-workers produced (carboxymethyl) chitosan-modified SPIONs (CMCS-SPIONs) by covalently binding CMCS to (3-aminopropyl) trimethoxysilane-treated SPIONs. The hMSCs have a preferential uptake of CMCS-coated SPIONs as compared to SPIONs likely due to the nonspecific adsorption [67, 128], although both show negative surface charge (CMCS-coated SPIONs: $-21.4 \mathrm{mV}$ vs. SPIONs: -13.6 $\mathrm{mV}$ ). Less than 100 CMCS-SPIONs labeled cells in agarose can be clearly detected by $1.5 \mathrm{~T}$ MR system.

Pullulan is a water-soluble polysaccharide with a repeated unit of maltotriose condensed through a-1, 6 linkage. Jo [68] developed two pullulan derivates, including cationized ethylenediamine modified pullulan (ED-pullulan) and anionized succinic anhydride modified pullulan (Suc-pullulan). The Pullulan and/or its derivate-coated SPIONs were synthesized by the conventional coprecipitation of ferric and ferrous ions in the presence of pullulan derivatives. This method was called in suit coating. Various pullulan or its derivate coated SPIONs with different sizes $(62 \mathrm{~nm}$ $\sim 161 \mathrm{~nm})$ and zeta potentials $(-6.9 \mathrm{mV} \sim+12 \mathrm{mV})$ were obtained by altering the mixing molar ratios of pullulan hydroxyl groups to ferric ions and mixing percentages among the pullulan, ED-pullulan and Suc-pullulan. Prussian blue staining revealed that positively-charged pullulan-SPIONs with the size less than $100 \mathrm{~nm}$ were internalized into almost all cells by co-culture for $1 \mathrm{~h}$. The internalized NPs retained in the cells without negative effects on the cells viability for 21 days. However, Fe content in MSCs dramatically decreased when MSCs treated by NPs with the particle size around $100 \mathrm{~nm}$ or the surface potential around $0 \mathrm{mV}$.

Heparin is a highly sulfated glycosaminoglycan molecule that interacts with various proteins containing heparin-binding domains within the extracellular matrix milieu. It has been widely used in drug delivery systems and tissue engineering to improve the biocompatibility and blood compatibility of biomaterials [129]. Recently, Lee and coworkers [69] synthesized SPIONs coated with unfractionated heparin (UFH-SPIOs) by in suit coating (Figure 5). The uptake efficiency of UFH-SPIO without the aid of transfection agents was greater than that of dextran coated SPIO by approximately 3 folds when treated for $1 \mathrm{~h}$. This was because the coating of heparin on the surface of NP increased its hydrophilicity, which promoted cell attachment to the NP surface. When the UFH-SPIO-labeled hMSCs were transplanted into the left renal subcapsular membranes of nude mice, they were successfully visualized and detected by $T_{2}$ weighted MRI imaging after a month.

\section{PEG}

Poly(ethylene glycol) (PEG) is a flexible and water-soluble polymer. The high hydrophilicity of PEG chains can render the iron oxide core soluble and stabilized in the aqueous media. Park's group [70] evaluated the potency of a library of commercial PEG derivatives (Laysan Bio, Inc, Arab, AL) as surface modifying agents for iron oxide NPs (IONPs) (Figure 6). The PEG library included PEG derivatives with variations in structural configurations (linear, four-arm and six-arm), molecular weights (1, 2, 3.4, 5, 10, $15 \mathrm{kDa}$, etc.). PEG derivatives modified IONPs were prepared by post-synthesis coating. With the increasing of the molecular weight, the number of branched chains and functionalities, higher stability and better dispersion could be attained. The result demonstrated that six-arm amine-functionalized PEG $\left(6\left(\mathrm{PEG}-\mathrm{NH}_{2}\right)\right)$ was a superior dispersion agent for the monodispersed SPIONs. However, PEG is well known for its "stealthy" effect and not favorable for most cells to uptake SPIONs with PEG shell protec- 
tion [130]. Therefore, SPIONP-6PEG-NH ${ }_{2}$ was modified by hyaluronic acid (HA), a targeting moiety, for stem cell uptake. IONP-6PEG-HA showed higher saturated magnetization and relaxivity as compared to Feridex ${ }^{\circledR}$. The amount of Fe inside MSCs was much higher for IONP-6PEG-HA (145.9 $\pm 15.2 \mathrm{ng} \mathrm{Fe} / 10^{5}$ cells) than that for Feridex ${ }^{\circledR}\left(45.1 \pm 3.9 \mathrm{ng} \mathrm{Fe} / 10^{5}\right.$ cells $)$, probably due to CD44-mediated endocytosis.

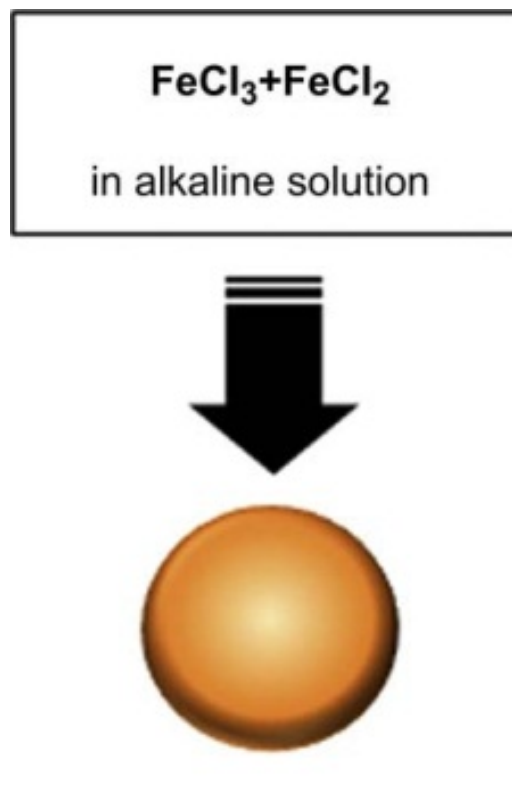

Iron oxide particle

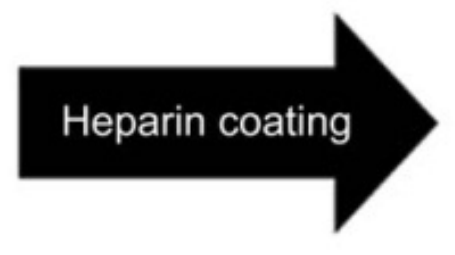

TEM

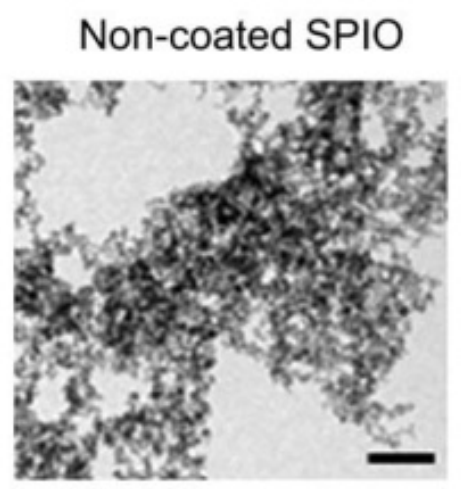

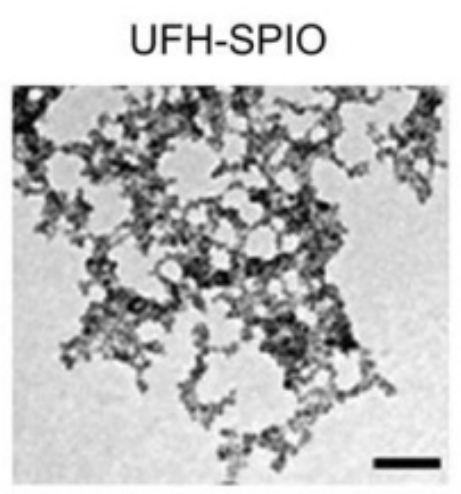

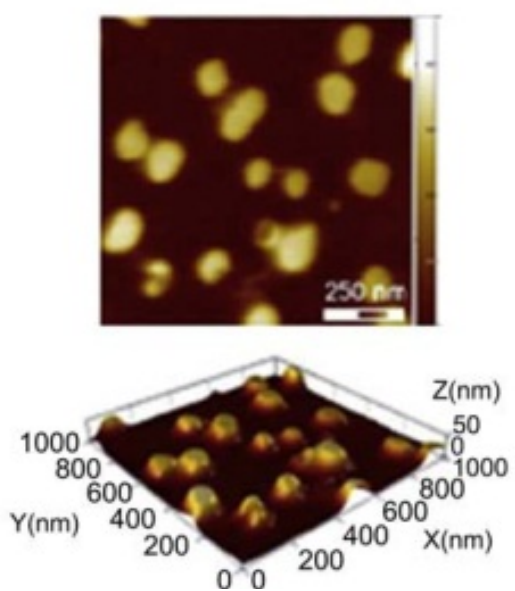

Fig 5. Schematic illustration of the preparation of UFH-SPIO; TEM images of non-coated and UFH coated SPIONs (non-coated SPIONs (left) and UFH-SPIONs (right), scale bar: $100 \mathrm{~nm}$ ); AFM images of UFH-SPIONs (height image (upper) and 3D image (lower)), reprinted with permission from ref. [69]. Copyright (2012) Elsevier. 


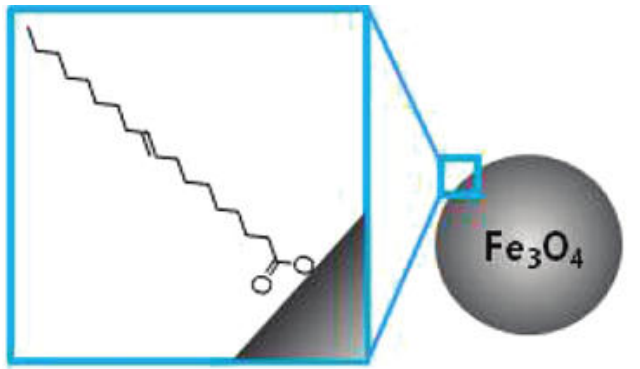

As-synthesized IONPs in organic solvent

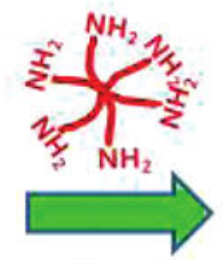

Functionalized PEGs

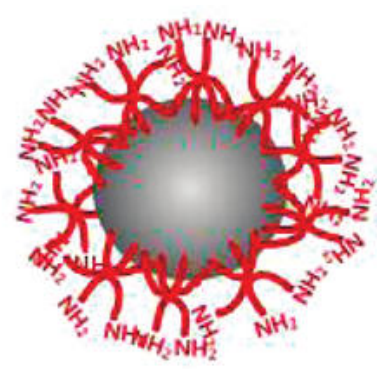

Aqueous phasedispersed IONPs

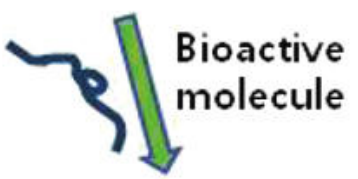

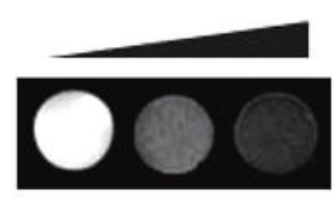

Cellular imaging

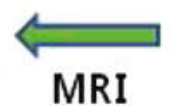

MRI

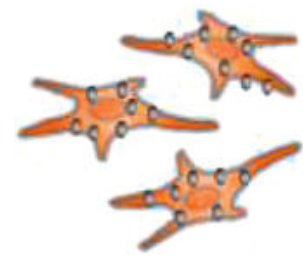

Cell labeling

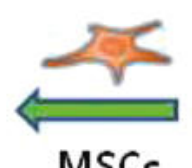

MSCs

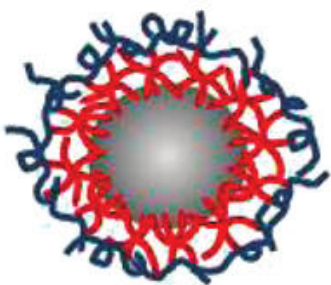

Biofunctionalized IONPs

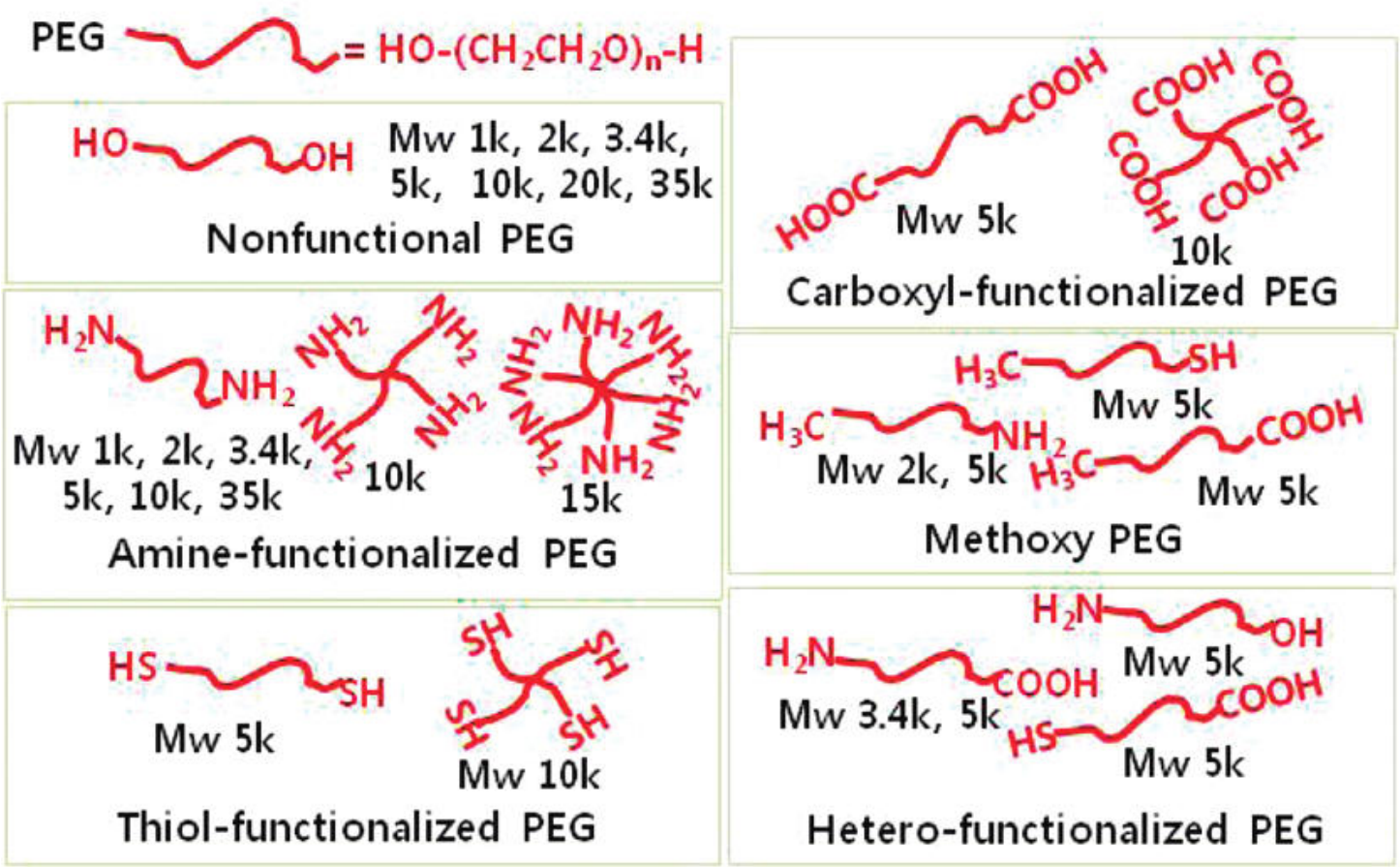

Fig 6. Schematic illustration of the procedure for dispersion of IONPs in an aqueous phase using a library of PEG derivatives followed by functionalization with bioactive molecules for cellular labeling and imaging. Inset shows oleic acid on IONP surface; reprinted with permission from ref [70]. Copyright (20II) American Chemical Society. 


\section{Other polymers}

Other synthetic polymer such as polyacrylic acid (PAA), poly(N,N-dimethylacrylamide) (PDMAAm), poly(DL-lactic acid-co- $\alpha, \beta-$ malic acid) copolymer (PLMA), poly(lactide-co-glycolide) (PLGA) and cellulose have been used to coat or encapsulate SPIONs.

PAA with many carboxylic acids on its backbone can strongly bind to the surface of SPION through multivalent anchoring points. The other free carboxylic groups of the PAA provide SPIONs with high hydrophobicity [131]. Our group reported monodispersed superparamagnetic $\mathrm{Fe}_{3} \mathrm{O}_{4}$ /polymethyl methacrylate (PMMA) composite NPs with high saturation magnetization (39 emu g-1, total mass) which were fabricated by a facile novel miniemulsion polymerization method [99]. The ferrofluid, MMA monomer and surfactants were co-sonicated and emulsified to form stable miniemulsion for polymerization. Then $\mathrm{Fe}_{3} \mathrm{O}_{4} /$ PAA composite NPs could be easily obtained by hydrolysis. Kim et al [71] prepared PAA coated SPIONs by exchanging the oleic acid on the surface of SPIONs with PAA. Subsequently, the free carboxylic acids of the PAA backbone were conjugated with 2-aminoethyl-trimethyl ammonium (TMA) by 1-ethyl-3-(3-dimethylaminopropyl)-carbodiimide (EDC) initiation to produce particles called as "TMA-SPION". The quaternary amine derivatives have a permanent positive charge $(+40 \mathrm{mV})$, independent of the physical $\mathrm{pH}$ in vivo. Prussian blue staining results showed that hMSCs treated with TMA-SPION $(25 \mu \mathrm{g} / \mathrm{mL}, 4 \mathrm{~h})$ acquired much more bright blue color from the stain than that treated with Feridex ${ }^{\circledR}$. TMA-SPION treatment had no effect on the differentiation of hMSCs. In vivo MRI study confirmed that TMA-SPION labeled cells were visible at least 7 d.

Horák's group produced PDMAAm-coated $\gamma-\mathrm{Fe}_{2} \mathrm{O}_{3} \mathrm{NPs}$ by the solution radical polymerization of DMAAm in the presence of SPIONs which were obtained by coprecipitation method and subsequent oxidation with sodium hypochlorite [64, 72]. In comparison to dextran coating (Feridex ${ }^{\circledR}$ ), PDMAAm coated magnetic NPs exhibited good dispersibility and high cellular internalization. However, it reduced magnetic susceptibility of SPIONs. PDMAAm-coated $\mathrm{\gamma}-\mathrm{Fe}_{2} \mathrm{O}_{3}$ labeled hMSCs provided significantly higher $r_{2}$ at both 0.5 and $4.7 \mathrm{~T}$ fields than Feridex ${ }^{\circledR}$ - and uncoated-iron oxide-labeled cells did due to its higher iron internalization. After the implantation of the three groups of iron oxide-labeled rMSCs $(5,000$ cells in $5 \mu \mathrm{L}$ of PBS) in rat brain, only PDMAAm-coated $\gamma-\mathrm{Fe}_{2} \mathrm{O}_{3}$ labeled cells were detected by MR.

PLMA, biodegradable polyester, is biocompatible and easy to be bifunctionalized through conjugating other imaging probes. Wang and coworkers [20] coated magnetic NPs with PLMA covalently bound fluorescein isothiocyanate (FITC) (FITC-PLMA-MNPs) by ligand exchange method (Figure 7). The FITC-PLMA-MNPs labeled hMSCs could be observed under confocal fluorescence microscopy and imaged by a $1.5 \mathrm{~T}$ MR scanner at a threshold cell number of 1200 without adverse effects on the osteogenic and adipogenic differentiation potentials of hMSCs.

PLGA and cellulose are Food and Drug Administration (FDA) approved for a variety of uses in humans and commonly employed for drug delivery and oral formulations. Shapiro's group incorporated monodispersed oleic $\mathrm{Fe}_{3} \mathrm{O}_{4} \quad(\sim 10 \mathrm{~nm})$ into micron-sized particles (MPs) and NPs of PLGA (fast degradation) and cellulose (slow degradation) using an oil-in-water single emulsion technique [132]. For all particles studied, SPIONs-loaded PLGA (505 Fe $\mathrm{mM}^{-1} \mathrm{~s}^{-1}$ ) and cellulose NPs (399 $\left.\mathrm{Fe} \mathrm{mM}^{-1} \mathrm{~s}^{-1}\right)$ displayed higher relaxivity values per millimole of $\mathrm{Fe}$, while had a much lower relaxivity per particle compared to PLGA MPs. Relaxivity of PLGA particles decreased faster than that of the cellulose particles after the incubation in endosomal mimicking solution (citrate buffer pH5.5). Without the aid of TAs, magnetic PLGA MPs showed a much higher labeling efficiency in MSCs compared to Feridex®/PLL as indicated by higher iron content per cell. $\mathrm{Xu}$ and coworkers [73] also reported oleic acid stabilized SPIONs (10 $\mathrm{nm}$ core size) encapsulated in PLGA (with carboxyl end-groups) using a single emulsion method. The yielding SPION/PLGA-MPs $(0.8-3 \mu \mathrm{m})$ had higher $r_{2}$ relaxivity (316.6 $\mathrm{Fe} \mathrm{mM}^{-1} \mathrm{~s}^{-1}$ ) compared to SPIONs $\left(61.16 \mathrm{mM}^{-1} \mathrm{~s}^{-1}\right)$ as a result of the SPION aggregation in PLGA. After transplantation of labeled MSCs into mouse, average $1 / T_{2} \quad\left(R_{2}\right)$ signal from SPION/PLGA-MPs was approximately twice that of the signal generated from SPIONs. Moreover, this MPs enhanced residence time inside MSCs (3-fold) compared to SPIONs. The fabrication and internalization of SPION/PLGA-MPs into MSCs are shown in Figure 8. Therefore, SPIONs loaded polymeric MPs are also promising contrast agents for cellular MRI. 
$\underset{\mathrm{CH}_{3}}{\mathrm{HOH}} \stackrel{120^{\circ} \mathrm{C} / \mathrm{Nac}}{\mathrm{O}} \underset{\text { Polycond. }}{\mathrm{O}}-\mathrm{COH}_{\mathrm{CH}_{3}}^{\mathrm{O}} \underset{\mathrm{O}}{\mathrm{CH}_{3}} \mathrm{OH}$

DL-lactic acid

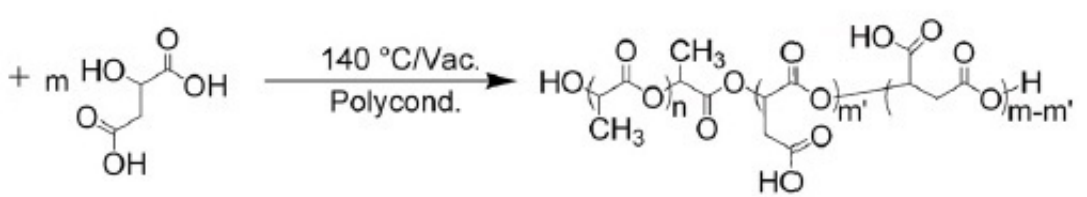

DL-malic acid

PLMA<smiles>CC(O)C(=O)OC(C)(C)C(=O)OC(=O)C(=O)OC(C)(C)C(=O)CC(=O)NCCNC(=S)Nc1ccc(-c2c3c(C(=O)O)cc(=O)cc-3oc3cc(O)ccc23)c(C(=O)O)c1</smiles>

FITC-PLMA

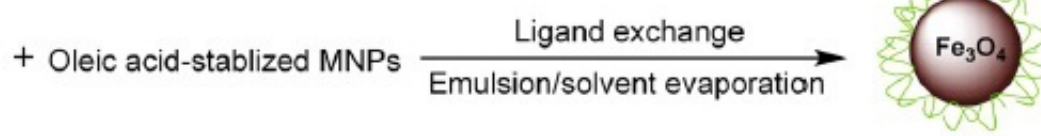

FITC-PLMA-MNPS

Fig 7. Schematic diagram and reaction scheme for FITC-PLMA-MNPs; reprinted with permission from ref.[20]. Copyright (2010) Elsevier.

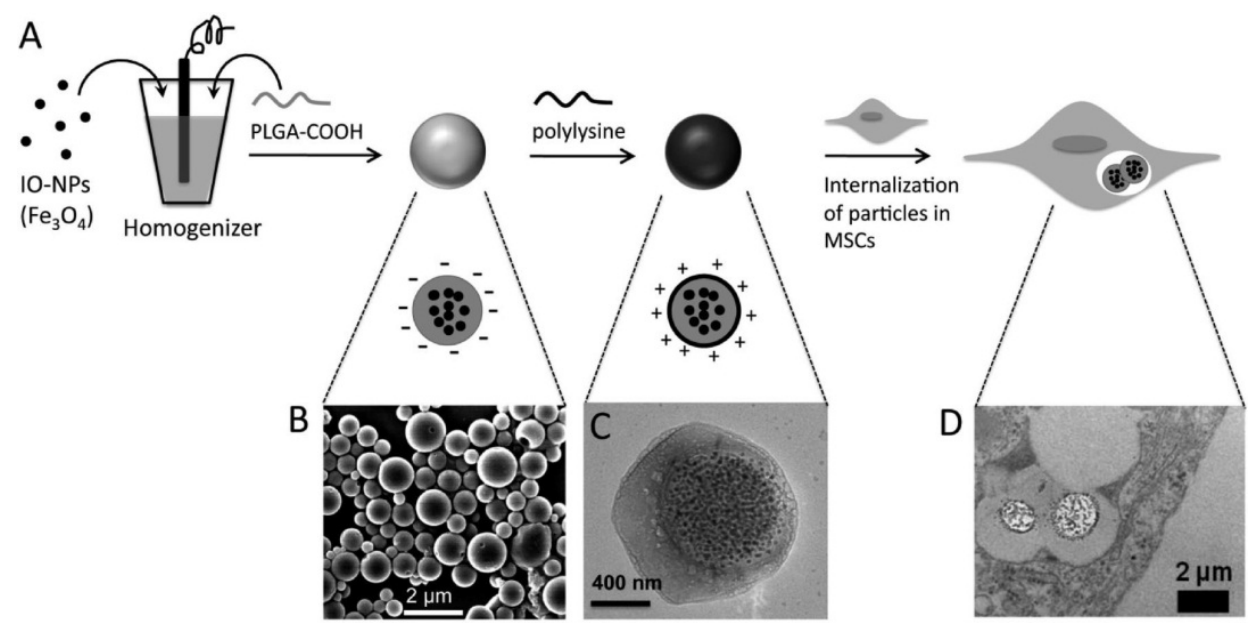

Fig 8. SPIONs/PLGA-MPs preparation and internalization by MSCs. (A) Schematic illustration of the preparation of SPIONs/PLGA-MPs with single emulsion method. (B) SEM image of SPIONs /PLGA-MPs. (C) TEM image of a representative SPIONs/PLGA-MP. (D) TEM image of SPIONs/PLGA-MPs internalized in a MSC, reprinted with permission from ref. [73]. Copyright (2012) American Chemical Society. 


\section{Small molecule ligands}

Small molecule ligands such as citric acid and mannose have been exploited as a coating material for SPIONs, which provides stability to the NPs in solution and is also helpful for cellular uptake.

Andreas et al [74] prepared citrate-coated SPIONs by simply mixing citrate acid and SPIONs prepared through coprecipitation in one step. Citrate-coated SPIONs showed negatively charged and hydrophilic surface, due to the exposure of their terminal carboxylic acid groups to the solvent [52]. Compared to the commercial NPs, the citrate-coated SPIONs were effectively internalized by MSCs at 25 $\mu \mathrm{g} / \mathrm{mL}$ of Fe in the cultivation medium (citrate-coated SPIONs $69.6 \pm 5.1 \mathrm{Fe} \mathrm{pg} /$ cell, Resovist $^{\circledR} 1.3 \pm 2.3 \mathrm{Fe}$ $\mathrm{pg} /$ cell and Endorem ${ }^{\mathrm{TM}} 4.9 \pm 2.7 \mathrm{Fe} \mathrm{pg} /$ cell). The high labeling efficiency may be explained by an altered endocytotic uptake mechanism due to the highly negative surface charge [77, 133] and/or large size after aggregation in cell cultivation medium [86]. Transplanted citrate SPIONs-labeled MSCs in vivo showed a considerable larger volume and surface area of hypointensity compared to Endorem $^{\mathrm{TM}}$ labeled-MSCs.

D-Mannose-specific and energy independent transporter has been found on the surface of the majority of mammalian cells [134]. D-mannose-coated NPs are most likely transported into the cells through this mannose transporter. Horák et al [64, 75] prepared D-mannose-coated SPIOs by two methods: in suit coating in the mannose solution and post-synthesis coating with mannose. FTIR results indicated that the surface of $\gamma-\mathrm{Fe}_{2} \mathrm{O}_{3}$ NPs was covered with D-mannose, which could be attached to iron oxide NPs by the hydroxyl group located on the $\mathrm{C}_{2}$ carbon in the axial position. They found that D-mannose-coated SPIONs by in situ coating had a smaller size $(\sim 2 \mathrm{~nm})$ by TEM as compared with that by the post synthesis coating $(\sim 6 \mathrm{~nm})$. This small size was owing to the presence of D-mannose during precipitation, which interfered with the nucleation step of iron oxide formation. D-mannose-coated SPIONs by post-synthesis coating had higher cellular internalization (about $80 \%$ labeled MSCs) and relaxivity $r_{2}$ than those of Endorem ${ }^{\mathrm{TM}}$ and D-mannose-coated SPIONs obtained by in situ coating (about 50\% labeled MSCs).

\section{Silica}

Silica $\left(\mathrm{SiO}_{2}\right)$ with good biocompatibility is demonstrated to serve as a good coating material for magnetic NPs [76, 78, 130, 135]. Silica coating on the surface of SPIONs prevents their aggregation in aqueous solution, improves their chemical and biological stability, and provides better biocompatibility [76]. The hydroxyl groups exposed on the silica-coated SPIONs can be easily linked to different functional groups, such as amine and carboxylate. Moreover, silica provides a platform for multi-model probes by integrating SPIONs and other imaging probes such as fluorescent dye [136]. Usually, two strategies are exploited to prepare silica coating: 1) silica is formed in situ through a sol-gel process using precursors such as tetraethyl orthosilicate (TEOS) ; 2) micelles or inverse micelles are used to form the coating of silica on the iron oxide core $[76,77]$.

Wang's group [76] synthesized novel polyhedral crystalline SPIONs coated with aminosilica (SPIO@SiO $2-\mathrm{NH}_{2}$ ). The polyhedral SPIO was prepared by solvothermal treatment of the crude SPIONs, which was synthesized by coprecipitation. Aminosilica coating was formed on the surface of the recrystallized polyhedral SPIONs (SPIO@SiO $\left.2-\mathrm{NH}_{2}\right)$ through the hydrolysis of aminopropyltriethoxysilane (APTES). TEM image of the $\mathrm{SPIO} @ \mathrm{SiO}_{2}-\mathrm{NH}_{2}$ revealed an iron oxide core (dark dots)-silica shell (thin white layer around the dark dots) structure. ICP-OES and in vitro MRI results demonstrated that surface amine modification enhanced MSC-labeling efficiency of SPIO@SiO ${ }_{2}-\mathrm{NH}_{2} \mathrm{NPs}$ compared to $\mathrm{SPIO} @ \mathrm{SiO}_{2} \mathrm{NPs}$. Importantly, after being implanted in rabbit brain, the labeled MSCs would be visible in a 3T MR system for 8-12 weeks, which was longer compared to other reports due to the stability of $\mathrm{SiO}_{2}$ in cellular environment $[62,72]$.

The combination of MRI and optical imaging methods has the advantages of high spatial resolution from MRI and good sensitivity from optical imaging methods. Dye molecules can be easily incorporated into a silica shell. Yoon and coworkers [77] synthesized cobalt ferrite magnetic NPs coated with a shell of amorphous silica containing rhodamine B isothiocyanate (RITC) or fluorescein isothiocyanate (FITC) and PEG by a modified PVP method and the sol-gel process (Figure 9A). The thickness of the silica shell could be easily controlled by adjusting the MNPs/tetraethoxysilane (TEOS) ratio and dye-modified saline (Figure 9B). These silica-coated magnetic NPs incorporating RITC (MNPs@SiO $\mathrm{O}_{2}(\mathrm{RITC})$ ), achieves efficient MSC labeling. The labeled cells were bright, photostable, and easy to track in live NODSCID mice [136] and in an experimental rat model of liver cirrhosis [79] (Figure 10). Similarly, FITC-incorporated silica-coated core-shell SPIO NPs (SPIO@SiO 2 (FITC)) with diameters of 50 $\mathrm{nm}$, were synthesized by a water-in-oil reverse mi- 
celle method [78]. It could efficiently label hMSCs, via clathrin- and actin-dependent endocytosis. Detection threshold of labeled cell number in vitro was about $1 \times$
$10^{4}$ cells. Furthermore, $1.2 \times 10^{5}$ labeled cells could also be detected by clinical 1.5T-MRI in vivo.

A

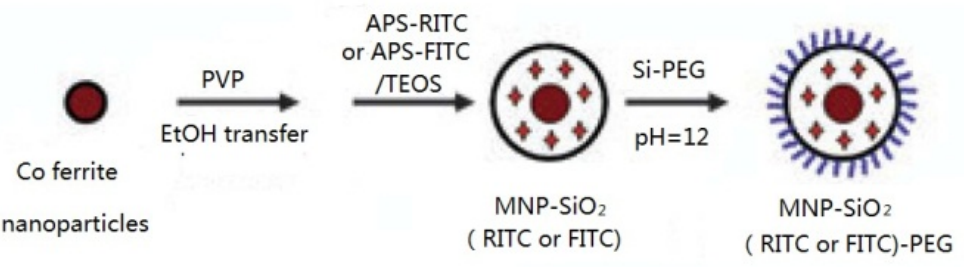

B
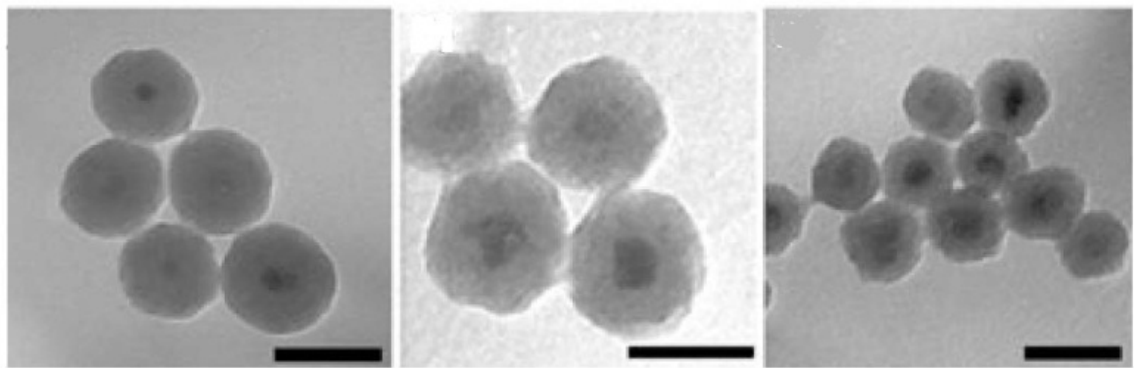

Fig 9. (A) Schematic illustration of the overall synthetic procedure for MNP-SiO $(\mathrm{RITC})$-PEG. (B) TEM images of Co ferrite-silica (core-shell) MNPs with controlled shell thicknesses. TEOS $/ \mathrm{MNP}=0.12 \mathrm{mg} / 4 \mathrm{mg}$, scale bar $=100 \mathrm{~nm}$ (left), TEOS/MNP $=0.06 \mathrm{mg} / 4 \mathrm{mg}$, scale bar $=50 \mathrm{~nm}$ (middle), TEOS/MNP = $0.03 \mathrm{mg} / 4 \mathrm{mg}$, scale bar $=50 \mathrm{~nm}$ (right). As the ratio of TEOS/MNP (w/w) decreases, the shell thickness decreases. Reprinted with permission from [77]. Copyright (2005) Wiley.

Fig 10. Optical, magnetic resonance (MR), and paraffin-embedded tissue images of a mouse injected with nanoparticle-labeled human UCB-derived MSCs (hMSCs).

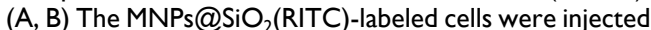
into four sites (I-IV) in the mouse's subcutaneous cavity (I, I $\times 10^{6} ; \mathrm{II}, 5 \times 10^{5} ; \mathrm{III}, \mathrm{I} \times 10^{5} ; \mathrm{IV}, 5 \times 10^{4}$ cells). Optical imaging shows that the labeled hMSCs express the RITC signal (A-I). With MRI, the coronal (A-2) and axial (A-3, A-4) planes, $T_{2}{ }^{*}$-weighted gradient echo pulse images show very hypointense and distorted dark areas (white arrows) in the abdominal wall. Subsequently, $I \times 10^{6}$ or $I$ $\times 10^{5}$ labeled hMSCs were injected into the liver via the portal vein, and 7 days after injection a liver MR image was obtained in the axial plane. Compared to the liver of control mice (B-I), the liver of the treated mice had punctuated dark contrast spots distributed in a very hypointensive area (B-2). Injection of $\mathrm{I} \times 10^{5}$ cells into the liver resulted in a dark spot, but the number and intensity of black contrast spots were lower than that in the liver injected with I $\times 10^{6}$ cells (B-3). After MRI to confirm that nanoparticle-positive hMSCs were present in the mouse liver (infused with I × $10^{5}$ nanoparticle-labeled hMSCs), the liver was harvested and fixed it in a $4 \%$ paraformaldehyde solution. The sectioned slides were observed with CLSM. In a representative histological finding, red fluorescence from nanoparticle-labeled hMSCs, is clearly visible (B-4). Reprinted with permission from [136]. Copyright (2010) Elsevier.
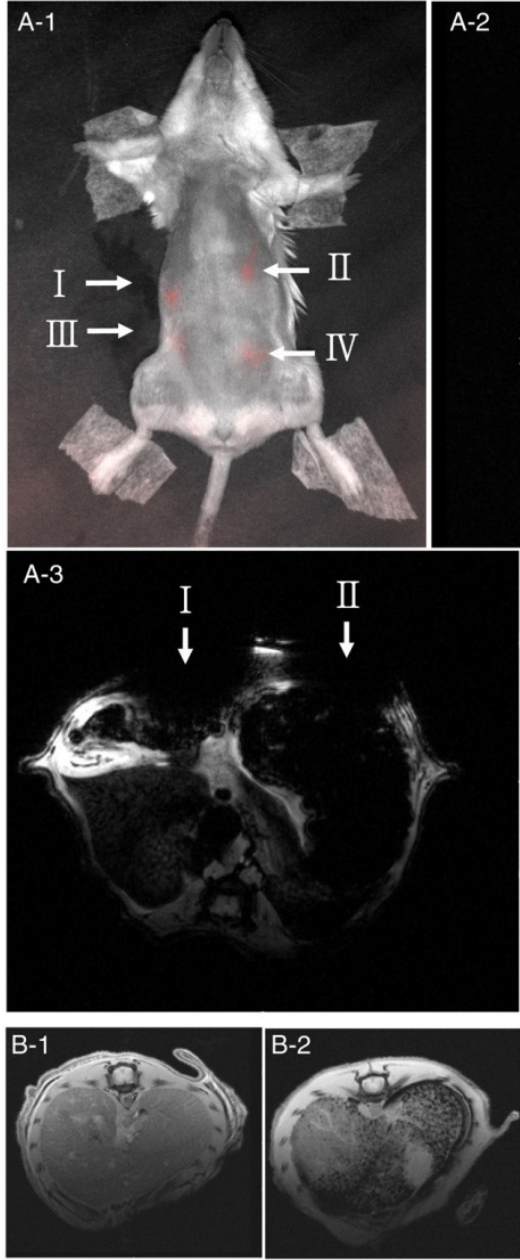
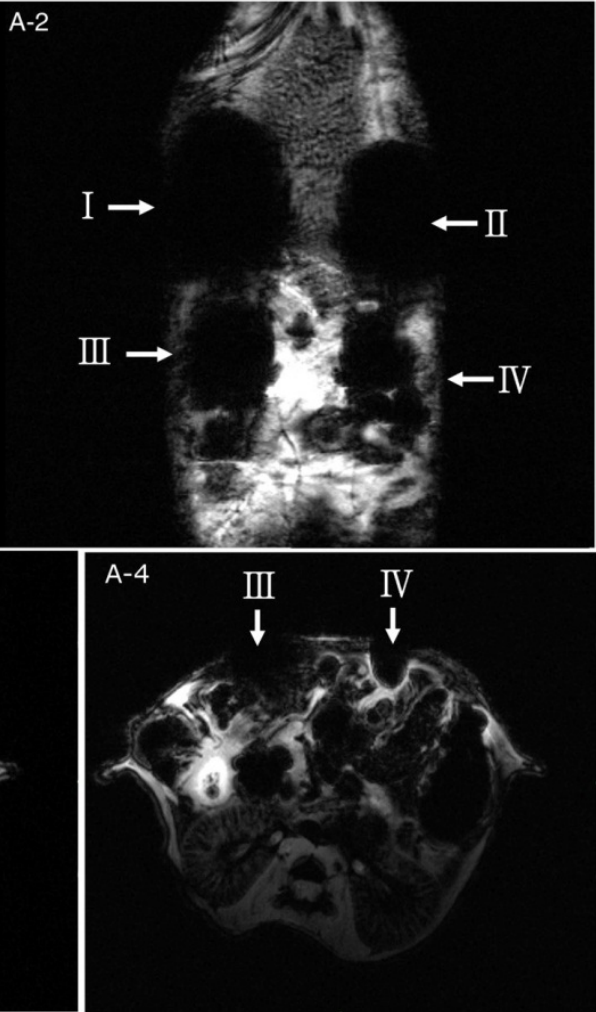
Mesoporous silica NPs (MSNs), in the form of stable aqueous dispersions, are emerging as good agents for biomedical imaging and drug/gene therapy. Huang's group developed tumbler-like magnetic/FITC-labeled mesoporous silica NPs (Mag-Dye@MSNs) [137], which were composed of silica coated SPIO (SPIO@SiO ${ }_{2}$ NPs co-condensed with FITC-incorporated mesoporous silica (FITC-MSNs) [80]. Mag-Dye@MSNs displayed much greater labeling efficiency compared to SPIO@SiO The Mag-Dye@MSNs labeled cells could be visualized in a clinical 1.5-T MRI system with a detectable threshold of about $1.2 \times 10^{4}$ labeled cell in vitro and $1 \times 10^{5}$ cells in vivo. Our group prepared novel SPIO-SiO $\mathrm{S}_{2}$ NPs which were composed of a nanospherical $\mathrm{Fe}_{3} \mathrm{O}_{4}$ /PMMA composite core and a periodic mesoporous silica shell by the combination of a modified sol-gel method and a dual-template strategy. The NPs exhibited homogeneity, superparamagnetism, high saturation magnetization and good magnetic responsiveness (Figure 11) [100]. They are promising MRI probes for stem cell labeling and tracking.

\section{Functional moieties}

Several small regions of proteins termed protein transduction domains (PTDs), including peptides from the human immunodeficiency virus (HIV) TAT protein and Herpes simplex virus (HSV), have received significant and widespread attention in the pharmaceutical and medical fields. They have the superior ability to deliver macromolecules, even NPs into living cells.

TAT peptide (GRKKRRQRRRGYK) purified from HIV TAT protein contains both transmembrane and nuclear localization signal. TAT-cross linked iron oxide (TAT-CLIO) was prepared by covalently conjugating CLIO-NH${ }_{2}$ to C-terminal cysteine side chain of tat-peptide [81]. The hNSCs labeled with tat-CLIO contained $2.15 \pm 0.3 \mathrm{Fe} \mathrm{pg} / \mathrm{cell}$, which was 59-fold, 430-fold and 6-fold higher than those of the hNSCs labeled with ferumoxides, monocrystalline iron oxide (MION) or CLIO-NH ${ }_{2}$, respectively [53].

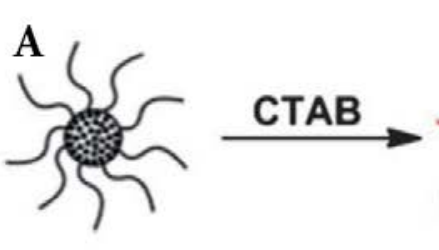

(1)

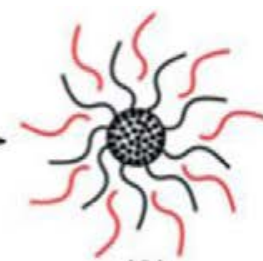

(2)

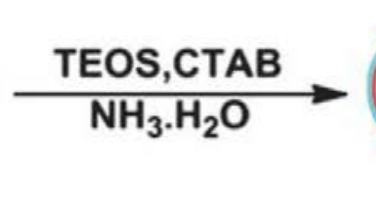

(3)

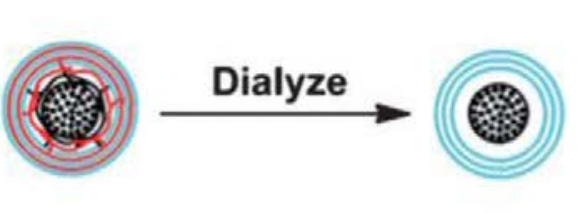

(4)

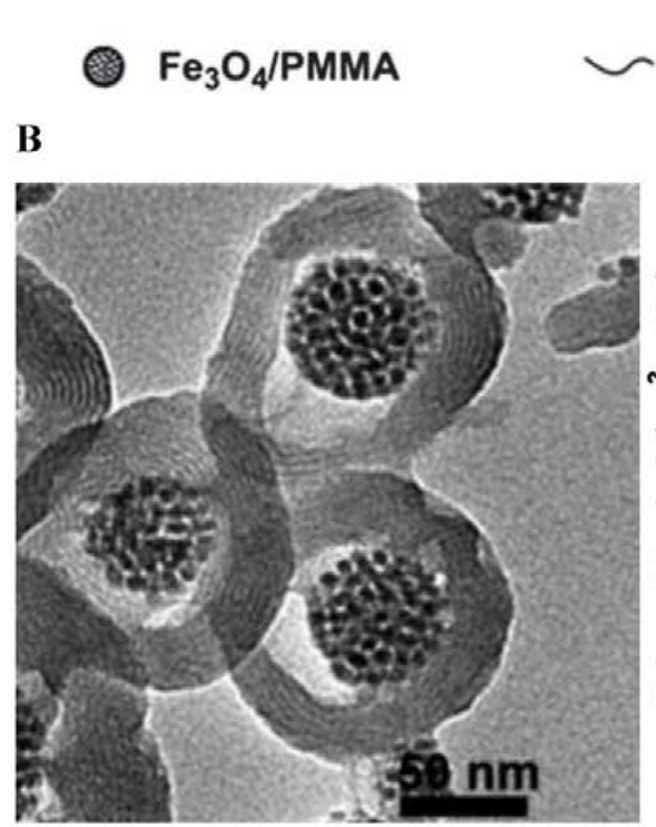

\section{SDBS}

CTAB

$\mathrm{SiO}_{2}$

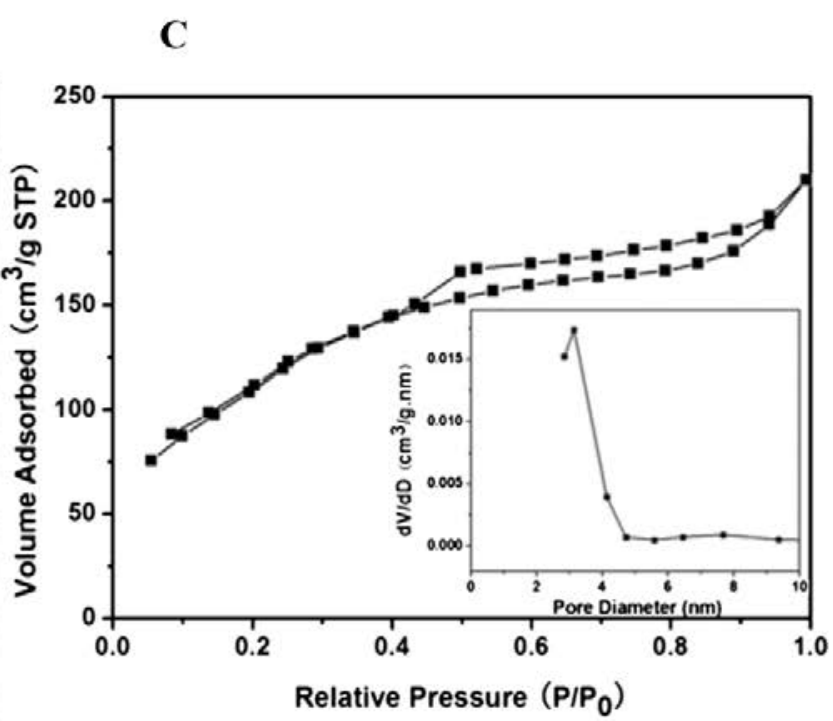

Fig I I. (A) The schematic synthesis of the $\mathrm{Fe}_{3} \mathrm{O}_{4} / \mathrm{PMMA} / \mathrm{SiO}_{2}$ nanorattles with periodic mesoporous shells; (B) $\mathrm{TEM}$ micrographs of the $\mathrm{Fe} \mathrm{O}_{3} / \mathrm{PMMA} / \mathrm{SiO}{ }_{2}$ nanorattles with periodic mesoporous shells; (C) $\mathrm{N}_{2}$ adsorption-desorption isotherm and corresponding pore size distribution (inset graph) of $\mathrm{Fe}_{3} \mathrm{O}_{4} / \mathrm{PMMA} / \mathrm{SiO}_{2}$ nanorattles with periodic mesoporous shells. Reprinted with permission from [I00]. Reproduced by permission of The Royal Society of Chemistry. 
Low molecular weight protamine (LMWP, VSRRRRRRGGRRRR) possessed with high arginine content and significant sequence similarity to that of TAT, was derived directly from native protamine by enzymatic digestion with thermolysin. LMWP enables the delivery of many compounds into cells, even an impermeable gelonin across tumor cells [116]. In addition, unlike other cationic proteins or peptides, the LMWP hardly activated complement systems and elicited negligible hypotensive or toxic responses in dogs [138]. LMWP modified SPIO (LMWP-SPIO) exhibited high $\mathrm{M}_{\mathrm{s}}$ values of $85 \mathrm{emu} / \mathrm{g}$ Fe [82], which was much higher than that of SPIO (approximately 65 emu/g Fe) [109]. The hMSCs labeled with LMWP-SPIO presented the highest iron content compared to those labeled with Federix ${ }^{\circledR}$ and the complex of Federix ${ }^{\circledR}$ with poly-L-lysine.

\section{Problems and perspectives}

SPIONs have gained intensive research interest in stem cell labeling due to their high MR sensitivity and amenability to surface modification. Despite their rapid advancement in magnetic NPs and MRI technologies for stem cell biology, several problems remain to be solved: 1) How to detect not only the location but also the function of the labeled cells? SPIONs combined with other artificial reporter genes [139] as MRI contrast agents probably hold promise in this regard, since the fate of the labeled cells can be probed. Moreover, MRI in conjugation with other noninvasive imaging modalities, such as PET, SPECT, ultrasound, and optical imaging, yield a hybrid imaging platform which may overcome the disadvantage of MRI [97, 140,141]. 2) What is the potential toxicity of SPIONs in vivo? For instance, after the SPION labeled cells being transplanted into the host, SPIONs influence not only the labeled cells, but also the liver and spleen of the host [97]. The process and effects are not completely clear. Systematic preclinical studies have to be conducted with standardized assays to assess the potential long-term toxicity of the in vivo use of SPIONs. 3) How to translate stem cell tracking from preclinical models to human? Until now, there have been very few clinical studies due to issues in technologies and ethics [24].

In conclusion, the newer "smart" SPIONs together with a more thorough understanding of label particle-cell-host interactions will greatly improve the applicability of SPIONs-based stem cell tracking and monitoring.

\section{Abbreviations}

$\mathrm{BLI}$, bioluminescence imaging; $\mathrm{CH}$, chitosan;
CLIO, cross-linked iron oxide; CT, computed tomography; Gd-DTPA, gadolinium diethylene-trianmine pentaacetic acid; FITC, fluoresceine isothiocyanate; FLI, fluorescence imaging; HA, hyaluronic acid; LMWP, low molecular weight protamine; Micron-sized particles, MPs; MR, magnetic resonance; MRI, magnetic resonance imaging; MSC, mesenchymal stem cells; MSNs, mesoporous silica nanoparticles; Nanoparticles, NPs, NSC, neural stem cell; PAA, poly(acrylic acid); PDMAAm, poly(N,N-dimethylacr ylamide); PEG, poly(ethylene glycol); PEG-PLA, poly(ethylene glycol)-poly(L-glutamic acid); PEI, poly(ethyleneimine); PEI-SA, stearic acid-grafted polyethyleneimine copolymers; PET, positron emission tomography; PLGA, poly(lactide-co-glycolide); PLL, poly-L-lysine); PLMA: poly(DL-lactic acid-co- $\alpha, \beta$-malic acid) copolymer; PMMA, poly(methylmethacrylate); $r_{1}$, longitudinal relaxivity; $r_{2}$, transverse relaxivity; RES, reticuloendothelial system; RITC: rhodamine B isothiocyanate; SPECT, single photon emission computed tomography; SPIONs, superparamagnetic iron oxide nanoparticles; $T_{1}$, longitudinal relaxation time; $T_{2}$, transverse relaxation time; TAs, transfection agents.

\section{Acknowledgment}

The work was supported by National Basic Research Program of China (2011CB606206), Program for New Century Excellent Talents in University (NCET-11-0350), and Science Foundation of China (51133004, 51273127 and 31070849)

\section{Competing Interests}

The authors have declared that no competing interest exists.

\section{References}

1. Ramos-Cabrer P and Hoehn M. MRI stem cell tracking for therapy in experimental cerebral ischemia. Transl Stroke Res. 2012; 3: 22-35.

2. Agudelo CA, Tachibana $\mathrm{Y}$, Noboru $\mathrm{T}$, Iida $\mathrm{H}$, and Yamaoka $\mathrm{T}$. Long-term in vivo magnetic resonance imaging tracking of endothelial progenitor cells transplanted in rat ischemic limbs and their angiogenic potential. Tissue Eng Part A. 2011; 17: 2079-89.

3. Green MD and Snoeck HW. Novel approaches for immune reconstitution and adaptive immune modeling with human pluripotent stem cells. BMC Med. 2011; 9: 51.

4. Sandhaus RA. Gene therapy meets stem cells. N Engl J Med. 2012; 366: 567-9.

5. Zhang XL, Wang G, Dong FR, and Wang ZM. Application of magnetic resonance imaging for monitoring stem cell transplantation for the treatment of cerebral ischemia. Neural Regen. Res. 2012;7: 1264-71.

6. Gupta PK, Das AK, Chullikana A, and Majumdar AS. Mesenchymal stem cells for cartilage repair in osteoarthritis. Stem Cell Res Ther. 2012; 3: 25 .

7. Longo UG, Petrillo S, Franceschetti E, Berton A, Maffulli N and Denaro V. Stem cells and gene therapy for cartilage repair. Stem Cells Int. 2012;:168385.

8. Zhao Y, Zhang Z, Wang J, Yin P, Zhou J, Zhen M, Cui W, Xu G, Yang D and Liu Z. Abdominal hernia repair with a decellularized dermal 
scaffold seeded with autologous bone marrow-derived mesenchymal stem cells. Artif Organs. 2012; 36: 247-55.

9. Ma B, Hankenson KD, Dennis JE, Caplan AI, Goldstein SA and Kilbourn MR. A simple method for stem cell labeling with fluorine 18. Nucl Med Biol. 2005; 32: 701-5.

10. Elhami E, Goertzen A, Xiang B, Deng J, Stillwell C, Mzengeza S, Arora R, Freed D and Tian G. Viability and proliferation potential of adipose-derived stem cells following labeling with a positron-emitting radiotracer. Eur J Nucl Med Mol Imaging. 2011; 38: 1323-34.

11. Patel D, Kell A, Simard B, Xiang B, Lin HY and Tian G. The cell labeling efficacy, cytotoxicity and relaxivity of copper-activated MRI/PET imaging contrast agents. Biomaterials. 2011; 32: 1167-76.

12. Bindslev L, Haack-Sorensen M, Bisgaard K, Kragh L, Mortensen S, Hesse B, Kjaer A and Kastrup J. Labelling of human mesenchymal stem cells with indium-111 for SPECT imaging: effect on cell proliferation and differentiation. Eur J Nucl Med Mol Imaging. 2006; 33: 1171-7.

13. Sheyn D, Kallai I, Tawackoli W, Cohn Yakubovich D, Oh A, Su S, Da X, Lavi A, Kimelman-Bleich N, Zilberman Y, Li N, Bae H, Gazit Z, Pelled G and Gazit D. Gene-modified adult stem cells regenerate vertebral bone defect in a rat model. Mol Pharm. 2011; 8: 1592-601.

14. Wolbank S, Peterbauer A, Wassermann E, Hennerbichler S, Voglauer R, van Griensven M, Duba HC, Gabriel C, and Redl H. Labelling of human adipose-derived stem cells for non-invasive in vivo cell tracking. Cell and Tissue Banking. 2007; 8: 163-77.

15. Baba K and Nishida K. Single-molecule tracking in living cells using single quantum dot applications. Theranostics. 2012; 2: 655-67.

16. Higuchi $\mathrm{Y}, \mathrm{Wu} \mathrm{C}$, Chang $\mathrm{KL}$, Irie $\mathrm{K}$, Kawakami S, Yamashita $\mathrm{F}$ and Hashida M. Polyamidoamine dendrimer-conjugated quantum dots for efficient labeling of primary cultured mesenchymal stem cells. Biomaterials. 2011; 32: 6676-6682.

17. Zhang Y. Quantum dot enabled molecular sensing and diagnostics. Theranostics. 2012; 2: 631-54.

18. Hsieh SC, Wang FF, Lin CS, Chen YJ, Hung SC and Wang YJ. The inhibition of osteogenesis with human bone marrow mesenchymal stem cells by CdSe/ZnS quantum dot labels. Biomaterials. 2006; 27: 1656-64.

19. Liu G, Ye X, Zhu Y, Li Y, Sun J, Cui L and Cao Y. Osteogenic differentiation of GFP-labeled human umbilical cord blood derived mesenchymal stem cells after cryopreservation. Cryobiology. 2011; 63: 125-8.

20. Wang L, Neoh KG, Kang ET, Shuter B and Wang SC. Biodegradable magnetic-fluorescent magnetite/poly(DL-lactic acid-co-alpha,beta-malic acid) composite nanoparticles for stem cell labeling. Biomaterials. 2010; 31: 3502-11.

21. Boddington SE, Henning TD, Jha P, Schlieve CR, Mandrussow L, DeNardo D, Bernstein HS, Ritner C, Golovko D, Lu Y, Zhao S and Daldrup-Link HE. Labeling human embryonic stem cell-Derived cardiomyocytes with indocyanine green for noninvasive tracking with optical imaging: an FDA-compatible alternative to firefly luciferase. Cell Transpl. 2010; 19: 55-65.

22. Gildehaus FJ, Haasters F, Drosse I, Wagner E, Zach C, Mutschler W, Cumming P, Bartenstein P and Schieker M. Impact of indium-111 oxine labelling on viability of human mesenchymal stem cells in vitro, and 3D cell-tracking using SPECT/CT in vivo. Mol Imaging Biol. 2011; 13: 1204-1214.

23. Rumenapp C, Gleich B and Haase A. Magnetic nanoparticles in magnetic resonance imaging and diagnostics. Pharm Res. 2012; 29: 1165-79.

24. Bulte JWM. In vivo MRI cell tracking: clinical studies. Am J Roentgenol. 2009; 193: 314-25.

25. Hu SL, Lu PG, Zhang LJ, Li F, Chen Z, Wu N, Meng H, Lin JK and Feng $\mathrm{H}$. In vivo magnetic resonance imaging tracking of SPIO-labeled human umbilical cord mesenchymal stem cells. J Cell Biochem. 2012; 113: 1005-1012.

26. Bhirde A, Xie J, Swierczewska M and Chen X. Nanoparticles for cell labeling. Nanoscale. 2011; 3: 142-53.

27. Liu G, Swierczewska M, Niu G, Zhang X and Chen X. Molecular imaging of cell-based cancer immunotherapy. Mol Biosyst. 2011; 7: 993-1003.

28. Akbarzadeh A, Samiei M and Davaran S. Magnetic nanoparticles: preparation, physical properties, and applications in biomedicine. Nanoscale Res Lett. 2012; 7: 1-13.

29. Berman SMC, Walczak P and Bulte JWM. Tracking stem cells using magnetic nanoparticles. Wiley Interdiscip Rev Nanomed Nanobiotechnol. 2011; 3: 343-55.

30. Xie J, Liu G, Eden HS, Ai H and Chen XY. Surface-engineered magnetic nanoparticle platforms for cancer imaging and therapy. Acc Chem Res. 2011; 44: 883-892.

31. Luo K, Tian J, Liu G, Sun J, Xia C, Tang H, Lin L, Miao T, Zhao X, Gao F, Gong Q, Song B, Shuai X, Ai H and Gu Z. Self-assembly of
$\mathrm{SiO} /$ Gd-DTPA-polyethylenimine nanocomposites as magnetic resonance imaging probes. J Nanosci Nanotechnol. 2010; 10: 540-8.

32. Guenoun J, Koning GA, Doeswijk G, Bosman L, Wielopolski PA, Krestin GP and Bernsen MR. Cationic Gd-DTPA liposomes for highly efficient labeling of mesenchymal stem cells and cell tracking with MRI. Cell Transplant. 2012; 21: 191-205.

33. Liu Y, He ZJ, Xu B, Wu QZ, Liu G, Zhu H, Zhong Q, Deng DY, Ai H, Yue Q, Wei Y, Jun S, Zhou G and Gong QY. Evaluation of cell tracking effects for transplanted mesenchymal stem cells with jetPEI/Gd-DTPA complexes in animal models of hemorrhagic spinal cord injury. Brain Res. 2011; 1391: 24-35.

34. G. Liu, H. Yang, X.M. Zhang, Y. Shao, and H. Jiang, MR imaging for the longevity of mesenchymal stem cells labeled with poly-L-lysine-Resovist complexes. Contrast Media Mol Imaging. 2010.5: 53-58.

35. Tseng CL, Shih IL, Stobinski L and Lin FH. Gadolinium hexanedione nanoparticles for stem cell labeling and tracking via magnetic resonance imaging. Biomaterials. 2010; 31: 5427-5435.

36. Tran LA, Krishnamurthy R, Muthupillai R, da Graça Cabreira-Hansen M, Willerson JT, Perin EC and Wilson LJ. Gadonanotubes as magnetic nanolabels for stem cell detection. Biomaterials. 2010; 31: 9482-91.

37. Lee HY, Lim NH, Seo JA, Yuk SH, Kwak BK, Khang G, Lee HB and Cho SH. Preparation and magnetic resonance imaging effect of polyvinylpyrrolidone-coated iron oxide nanoparticles. J Biomed Mater Res B Appl Biomater. 2006; 79: 142-150.

38. Luo K, Liu G, He B, Wu Y, Gong Q, Song B, Ai H and Gu Z. Multifunctional gadolinium-based dendritic macromolecules as liver targeting imaging probes. Biomaterials. 2011; 32: 2575-85.

39. Zhang B, Jiang B, Chen Y, Huang H, Xie Q, Kang M, Zhang H, Zhai C and $\mathrm{Wu}$ Y. Detection of viability of transplanted beta cells labeled with a novel contrast agent - polyvinylpyrrolidone-coated superparamagnetic iron oxide nanoparticles by magnetic resonance imaging. Contrast Media Mol Imaging. 2012; 7: 35-44.

40. Yang CY, Tai MF, Chen ST, Wang YT, Chen YF, Hsiao JK, Wang JL and Liu HM. Labeling of human mesenchymal stem cell: Comparison between paramagnetic and superparamagnetic agents. J Appl Phy. 2009;: 105.

41. Ke YQ, Hu CC, Jiang XD, Yang ZJ, Zhang HW, Ji HM, Zhou LY, Cai YQ, Qin $\mathrm{LS}$ and $\mathrm{Xu} \mathrm{RX}$. In vivo magnetic resonance tracking of Feridex-labeled bone marrow-derived neural stem cells after autologous transplantation in rhesus monkey. J Neurosci Meth. 2009; 179: 45-50.

42. Zhu WZ, Li X, Qi JP, Tang ZP, Wang W, Wei L and Lei H. Experimental Study of Cell Migration and functional differentiation of transplanted neural stem cells co-labeled with superparamagnetic iron oxide and Brdu in an ischemic rat model. Biomed Environ Sci. 2008; 21: 420-4.

43. Suzuki Y, Zhang S, Kundu P, Yeung AC, Robbins RC and Yang PC. In vitro comparison of the biological effects of three transfection methods for magnetically labeling mouse embryonic stem cells with ferumoxides. Magnetic Reson Med. 2007; 57: 1173-9.

44. Park BH, Jung JC, Lee GH, Kim TJ, Lee YJ, Kim JY, Kim YW, Jeong JH and Chang Y. Comparison of labeling efficiency of different magnetic nanoparticles into stem cell. Colloids Surf, A Physicochem Eng Asp. 2008; 313: 145-149.

45. Yang L, Xia Y, Zhao H, Zhao J and Zhu X. Magnetic resonance imaging of transplanted neural stem cells in parkinson disease rats. J Huazhong Univ Sci Techn -- Med Sci --. 2006; 26: 489-92.

46. Arbab AS, Yocum GT, Rad AM, Khakoo AY, Fellowes V, Read EJ and Frank JA. Labeling of cells with ferumoxides-protamine sulfate complexes does not inhibit function or differentiation capacity of hematopoietic or mesenchymal stem cells. NMR in Biomedicine. 2005; 18: 553-9.

47. Arbab AS, Yocum GT, Wilson LB, Parwana A, Jordan EK, Kalish H and Frank JA. Comparison of transfection agents in forming complexes with ferumoxides, cell labeling efficiency, and cellular viability. Mol Imaging. 2004; 3: 24-32.

48. Thu MS, Bryant LH, Coppola T, Jordan EK, Budde MD, Lewis BK, Chaudhry A, Ren J, Varma NRS, Arbab AS and Frank JA. Self-assembling nanocomplexes by combining ferumoxytol, heparin and protamine for cell tracking by magnetic resonance imaging. Nature Med. 2012; 18: 463-U165.

49. Arnold LJ, Dagan A, Gutheil J and Kaplan NO. Antineoplastic activity of poly(L-lysine) with some ascites tumor cells. Proc Natl Acad Sci U S A. 1979; 76: 3246-50

50. Bulte JWM, Kraitchman DL, Mackay AM and Pittenger MF. Chondrogenic differentiation of mesenchymal stem cells is inhibited after magnetic labeling with ferumoxides. Blood. 2004; 104: 3410-3412.

51. Liu YJ and Zhang N. Gadolinium loaded nanoparticles in theranostic magnetic resonance imaging. Biomaterials. 2012; 33: 5363-75. 
52. Laurent S, Forge D, Port M, Roch A, Robic C, Vander Elst L and Muller RN. Magnetic iron oxide nanoparticles: synthesis, stabilization, vectorization, physicochemical characterizations, and biological applications. Chem Rev. 2008; 108: 2064-110.

53. Song M, Moon WK, Kim Y, Lim D, Song IC and Yoon BW. Labeling efficacy of superparamagnetic iron oxide nanoparticles to human neural stem cells: Comparison of ferumoxides, monocrystalline iron oxide, cross-linked iron oxide (CLIO)-NH2 and tat-CLIO. Korean J Rad. 2007; 8: 365-71.

54. Pawelczyk E, Arbab AS, Chaudhry A, Balakumaran A, Robey PG and Frank JA. In vitro model of bromodeoxyuridine or iron oxide nanoparticle uptake by activated macrophages from labeled stem cells: implications for cellular therapy. Stem Cells. 2008; 26: 1366-75.

55. Terrovitis J, Stuber M, Youssef A, Preece S, Leppo M, Kizana E, Schaer M, Gerstenblith G, Weiss RG, Marban E and Abraham MR. Magnetic resonance imaging overestimates ferumoxide-labeled stem cell survival after transplantation in the heart. Circulation. 2008; 117: 1555-62.

56. Berry I, Benderbous S, Ranjeva JP, Gracia-Meavilla D and Claude Manelfe DLB. Contribution of sinerem@ used as blood-Pool contrast agent: detection of cerebral blood volume hanges during apnea in the rabbit. Magn Reson Med. 1996; 36: 415-9.

57. Li W, Tutton S, Vu AT, Pierchala L, Li BS, Lewis JM, Prasad PV and Edelman RR. First-pass contrast-enhanced magnetic resonance angiography in humans using ferumoxytol, a novel ultrasmall superparamagnetic iron oxide (USPIO)-based blood pool agent. J Magn Reson Imaging. 2005; 21: 46-52.

58. Jung CW. Surface properties of superparamagnetic iron oxide MR contrast agents: ferumoxides, ferumoxtran, ferumoxsil. Magn Reson Imaging. 1995; 13: 675-91.

59. Reimer P, Marx C, Rummeny EJ, Muller M, Lentschig M, Balzer T, Dietl KH, Sulkowski U, Berns T, Shamsi K and Peters PE. SPIO-enhanced 2D-TOF MR angiography of the portal venous system: results of an intraindividual comparison. J Magn Reson Imaging. 1997; 7: 945-49.

60. Kellar KE, Fujii DK, Gunther WH, Briley-Saebo K, Bjornerud A, Spiller M and Koenig SH. NC100150 Injection, a preparation of optimized iron oxide nanoparticles for positive-contrast MR angiography. J Magn Reson Imaging. 2000; 11: 488-94.

61. Shapiro EM, Skrtic S, Sharer K, Hill JM, Dunbar CE and Koretsky AP. MRI detection of single particles for cellular imaging. Proc Natl Acad Sci U S A. 2004; 101: 10901-6.

62. Ju S, Teng G, Zhang Y, Ma M, Chen F and Ni Y. In vitro labeling and MRI of mesenchymal stem cells from human umbilical cord blood. Magnetic Resonance Imaging. 2006; 24: 611-7.

63. Babič M, Horák D, Trchová M, et al. Poly(l-lysine)-modified iron oxide nanoparticles for stem cell labeling. Bioconj Chem. 2008; 19: 740-50.

64. Horák D, Babic M, Jendelová P, Herynek V, Trchová M, Likavčanová K, Kapcalová M, Hájek M and Syková E. Effect of different magnetic nanoparticle coatings on the efficiency of stem cell labeling. J Magn Magn Mater. 2009; 321: 1539-47.

65. Liu G, Wang Z, Lu J, Xia C, Gao F, Gong Q, Song B, Zhao X, Shuai X, Chen $\mathrm{X}, \mathrm{Ai} \mathrm{H}$ and $\mathrm{Gu} \mathrm{Z}$. Low molecular weight alkyl-polycation wrapped magnetite nanoparticle clusters as MRI probes for stem cell labeling and in vivo imaging. Biomaterials. 2011; 32: 528-537.

66. Guo R, Cao N, Zhang F, Wang Y, Wen X, Shen J and Shuai X. Controllable labelling of stem cells with a novel superparamagnetic iron oxide-loaded cationic nanovesicle for MR imaging. Eur Radiol. 2012;22: 2328-37.

67. Shi Z, Neoh KG, Kang ET, Shuter B, Wang SC, Poh C and Wang W. (Carboxymethyl)chitosan-modified superparamagnetic iron oxide nanoparticles for magnetic resonance imaging of stem cells. ACS Applied Materials \& Interfaces. 2008; 1: 328-35.

68. Jo JI, Aoki I and Tabata Y. Design of iron oxide nanoparticles with different sizes and surface charges for simple and efficient labeling of mesenchymal stem cells. Journal of Controlled Release. 2010; 142: 465-73.

69. Lee JH, Jung MJ, Hwang YH, Lee YJ, Lee S, Lee DY and Shin H. Heparin-coated superparamagnetic iron oxide for in vivo MR imaging of human MSCs. Biomaterials. 2012; 33: 4861-71.

70. Chung HJ, Lee H, Bae KH, Lee Y, Park J, Cho SW, Hwang JY, Park H, Langer R, Anderson D and Park TG. Facile Synthetic route for surface-functionalized magnetic nanoparticles: cell labeling and magnetic resonance imaging studies. ACS Nano. 2011; 5: 4329-36.

71. Kim H, Dae HM, Park C, Kim EO, Kim D, Kim IH, Kim YH and Choi Y. A highly sensitive magnetite nanoparticle as a simple and rapid stem cell labelling agent for MRI tracking. J Mater Chem. 2011; 21: 7742-7.

72. Babič M, Horák D, Jendelová P, Glogarová KI, Herynek VT, Trchová M, Likavčanová KN, Lesný $\mathrm{P}$, Pollert $\mathrm{E}$, Hájek $\mathrm{M}$ and Syková $\mathrm{E}$.
Poly(N,N-dimethylacrylamide)-coated maghemite nanoparticles for stem cell labeling. Bioconj Chem. 2009; 20: 283-94.

73. $\mathrm{Xu}$ C, Miranda-Nieves D, Ankrum JA, Matthiesen ME, Phillips JA, Roes I, Wojtkiewicz GR, Juneja V, Kultima JR, Zhao W, Vemula PK, Lin CP, Nahrendorf M and Karp JM. Tracking mesenchymal stem cells with iron oxide nanoparticle loaded poly(lactide-co-glycolide) microparticles. Nano Lett. 2012; 12: 4131-9.

74. Andreas K, Georgieva R, Ladwig M, Mueller S, Notter M, Sittinger M and Ringe J. Highly efficient magnetic stem cell labeling with citrate-coated superparamagnetic iron oxide nanoparticles for MRI tracking. Biomaterials. 2012; 33: 4515-25.

75. Horák D, Babič M, Jendelová P, Herynek V, Trchová M, Pientka Z, Pollert E, Hájek $\mathrm{M}$ and Syková E. D-Mannose-modified iron oxide nanoparticles for stem cell labeling. Bioconjugate Chemistry. 2007; 18: 635-44.

76. Wang HH, Wang YXJ, Leung KCF, Au DWT, Xuan S, Chak CP, Lee SKM, Sheng H, Zhang G, Qin L, Griffith JF and Ahuja AT. Durable mesenchymal stem cell labelling by using polyhedral superparamagnetic iron oxide nanoparticles. Chem - A Eur J. 2009; 15: 12417-25.

77. Yoon TJ, Kim JS, Kim BG, Yu KN, Cho MH and Lee JK. Multifunctional nanoparticles possessing a "magnetic motor effect" for drug or gene delivery. Angew Chem Int Ed. 2005; 44: 1068-71.

78. Lu CW, Hung Y, Hsiao JK, Yao M, Chung TH, Lin YS, Wu SH, Hsu SC, Liu HM, Mou CY, Yang CS, Huang DM and Chen YC. Bifunctional magnetic silica nanoparticles for highly efficient human stem cell labeling. Nano Lett. 2007; 7: 149-54.

79. Kim TH, Kim JK, Shim W, Kim SY, Park TJ and Jung JY. Tracking of transplanted mesenchymal stem cells labeled with fluorescent magnetic nanoparticle in liver cirrhosis rat model with 3-T MRI. Magnc Reson Imaging. 2010; 28: 1004-13.

80. Huang DM, Hung Y, Ko BS, Hsu SC, Chen WH, Chien CL, Tsai CP, Kuo CT, Kang JC, Yang CS, Mou CY and Chen YC. Highly efficient cellular labeling of mesoporous nanoparticles in human mesenchymal stem cells: implication for stem cell tracking. FASEB J. 2005; 19: 2014-6.

81. Wunderbaldinger $P$, Josephson $L$ and Weissleder $R$. Tat peptide directs enhanced clearance and hepatic permeability of magnetic nanoparticles. Bioconj Chem. 2002; 13: 264-8

82. Suh JS, Lee JY, Choi YS, Yu F, Yang V, Lee SJ, Chung CP and Park YJ. Efficient labeling of mesenchymal stem cells using cell permeable magnetic nanoparticles. Biochem Biophy Res Co. 2009; 379: 669-75.

83. Doherty GJ and McMahon HT. Mechanisms of endocytosis. Annu Rev Biochem. 2009; 78: 857-902.

84. Bae H, Ahmad T, Rhee I, Chang Y, Jin SU and Hong S. Carbon-coated iron oxide nanoparticles as contrast agents in magnetic resonance imaging. Nanoscale Res Lett. 2012; 7: 44.

85. Conner SD and Schmid SL. Regulated portals of entry into the cell. Nature. 2003; 422: 37-44.

86. Thorek DL and Tsourkas A. Size, charge and concentration dependent uptake of iron oxide particles by non-phagocytic cells. Biomaterials. 2008; 29: 3583-90.

87. Rejman J, Oberle V, Zuhorn IS and Hoekstra D. Size-dependent internalization of particles via the pathways of clathrinand caveolae-mediated endocytosis. Biochem J. 2004; 377: 159-69.

88. Hu JG, Fu SL, Wang YX, Li Y, Jiang XY, Wang XF, Qiu MS, Lu PH and $\mathrm{Xu}$ XM. Platelet-derived growth factor-AA mediates oligodendrocyte lineage differentiation through activation of extracellular signal-regulated kinase signaling pathway. Neuroscience. 2008; 151: 138-47.

89. Li L, Nie Y, Zhu R, Shi S, Luo K, He B, Yang Y, Yang J and Gu Z. Preparation and gene delivery of alkaline amino acids-based cationic liposomes. Arch Pharm Res. 2008; 31: 924-31.

90. Li L, Song H, Luo K, He B, Nie Y, Yang Y, Wu Y and Gu Z. Gene transfer efficacies of serum-resistant amino acids-based cationic lipids: Dependence on headgroup, lipoplex stability and cellular uptake. Int J Pharm. 2011; 408: 183-90.

91. Luo K, Li C, Wang G, Nie Y, He B, Wu Y and Gu Z. Peptide dendrimers as efficient and biocompatible gene delivery vectors: Synthesis and in vitro characterization. J Contr Rel. 2011; 155: 77-87.

92. Luo K, Li C, Li L, She W, Wang G and Gu Z. Arginine functionalized peptide dendrimers as potential gene delivery vehicles. Biomaterials. 2012; 33: 4917-27.

93. Yu C, Zhao J, Guo Y, Lu C, Ma X and Gu Z. A novel method to prepare water-dispersible magnetic nanoparticles and their biomedical applications: Magnetic capture probe and specific cellular uptake. J Biomed Mater Res A. 2008; 87A: 364-72.

94. Dousset V, Tourdias T, Brochet B, Boiziau C and Petry KG. How to trace stem cells for MRI evaluation? J Neurol Sci. 2008; 265: 122-6. 
95. Bulte JW, Douglas T, Witwer B, Zhang SC, Strable E, Lewis BK, Zywicke $\mathrm{H}$, Miller B, van Gelderen P, Moskowitz BM, Duncan ID and Frank JA. Magnetodendrimers allow endosomal magnetic labeling and in vivo tracking of stem cells. Nat Biotechnol. 2001; 19: 1141-7.

96. Ai H. Layer-by-layer capsules for magnetic resonance imaging and drug delivery. Adv Drug Deliver Rev. Reviews. 2011; 63: 772-88.

97. Xu C, Mu L, Roes I, Miranda-Nieves D, Nahrendorf M, Ankrum JA, Zhao W and Karp JM. Nanoparticle-based monitoring of cell therapy. Nanotechnology. 2011; 22: 494001.

98. Perez JM, Josephson L, O'Loughlin T, Hogemann D and Weissleder R. Magnetic relaxation switches capable of sensing molecular interactions. Nat Biotechnol. 2002; 20: 816-20.

99. Lan F, Liu KX, Jiang W, Zeng XB, Wu Y and Gu ZW. Facile synthesis of monodisperse superparamagnetic Fe3O4/PMMA composite nanospheres with high magnetization. Nanotechnology. 2011; 22: 225604

100. Lan F, Hu H, Jiang W, Liu K, Zeng X, Wu Y and Gu Z. Synthesis of superparamagnetic $\mathrm{Fe} 3 \mathrm{O} 4 / \mathrm{PMMA} / \mathrm{SiO} 2$ nanorattles with periodic mesoporous shell for lysozyme adsorption. Nanoscale. 2012; 4: 2264.

101. Bowen CV, Zhang X, Saab G, Gareau PJ and Rutt BK. Application of the static dephasing regime theory to superparamagnetic iron-oxide loaded cells. Magn Reson Med. 2002; 48: 52-61.

102. Lee JH, Huh YM, Jun YW, Seo JW, Jang JT, Song HT, Kim S, Cho EJ, Yoon HG, Suh JS and Cheon J. Artificially engineered magnetic nanoparticles for ultra-sensitive molecular imaging. Nat Med. 2007; 13: 95-9.

103. Basti H, Ben Tahar L, Smiri LS, Herbst F, Vaulay MJ, Chau F, Ammar S and Benderbous S. Catechol derivatives-coated $\mathrm{Fe} 3 \mathrm{O} 4$ and gamma-Fe2O3 nanoparticles as potential MRI contrast agents. J Colloid Interface Sci. 2010; 341: 248-54.

104. Cromer Berman SM, Kshitiz, Wang CJ, Orukari I, Levchenko A, Bulte JW and Walczak P. Cell motility of neural stem cells is reduced after SPIO-labeling, which is mitigated after exocytosis. Magn Reson Med. 2013; 69: 255-62.

105. Lewinski N, Colvin V and Drezek R. Cytotoxicity of nanoparticles. Small. 2008; 4: 26-49.

106. Bulte JW and Kraitchman DL. Iron oxide MR contrast agents for molecular and cellular imaging. NMR Biomed. 2004; 17: 484-99.

107. Chen YC, Hsiao JK, Liu HM, Lai IY, Yao M, Hsu SC, Ko BS, Chen YC, Yang CS and Huang DM. The inhibitory effect of superparamagnetic iron oxide nanoparticle (Ferucarbotran) on osteogenic differentiation and its signaling mechanism in human mesenchymal stem cells. Toxicol Appl Pharmacol. 2010; 245: 272-9.

108. Kedziorek DA, Muja N, Walczak P, Ruiz-Cabello J, Gilad AA, Jie CC and Bulte JW. Gene expression profiling reveals early cellular responses to intracellular magnetic labeling with superparamagnetic iron oxide nanoparticles. Magn Reson Med. 2010; 63: 1031-1043.

109. Lu AH, Salabas EL and Schüth F. Magnetic nanoparticles: synthesis, protection, functionalization, and application. Angew Chem Int Ed. 2007; 46: 1222-44

110. Jiang W, Wu Y, He B, Zeng X, Lai K and Gu Z. Effect of sodium oleate as a buffer on the synthesis of superparamagnetic magnetite colloids. J Colloid Interf Sci. 2010; 347: 1-7.

111. Jiang W, Lai KL, Hu H, Zeng XB, Lan F, Liu KX, Wu Y and Gu ZW. The effect of $[\mathrm{Fe} 3+] /[\mathrm{Fe} 2+]$ molar ratio and iron salts concentration on the properties of superparamagnetic iron oxide nanoparticles in the water/ethanol/toluene system. J Nanopart Res. 2011; 13: 5135-45.

112. Neoh KG and Kang ET. Surface modification of magnetic nanoparticles for stem cell labeling. Soft Matter. 2012; 8: 2057-69.

113. Zhu R, Jiang W, Pu Y, Luo K, Wu Y, He B and Gu Z. Functionalization of magnetic nanoparticles with peptide dendrimers. J Mater Chem. 2011; 21: 5464-74

114. Hyeon T, Lee SS, Park J, Chung Y and Na HB. Synthesis of highly crystalline and monodisperse maghemite nanocrystallites without a size-selection process. J Am Chem Soc. 2001; 123: 12798-801.

115. Ge S, Shi X, Sun K, Li C, Baker JR, Banaszak Holl MM andOrr BG. A facile hydrothermal synthesis of iron oxide nanoparticles with tunable magnetic properties. J Phys Chem C Nanomater Interfaces. 2009; 13: 13593-9.

116. Dai Z, Meiser F and Mohwald H. Nanoengineering of iron oxide and iron oxide/silica hollow spheres by sequential layering combined with a sol-gel process. J Colloid Interface Sci. 2005; 288: 298-300.

117. Stephen ZR, Kievit FM and Zhang M. Magnetite nanoparticles for medical MR imaging. Mater Today (Kidlington). 2011; 14: 330-8.

118. Sun S, Zeng H, Robinson DB, Raoux S, Rice PM, Wang SX and Li G. Monodisperse MFe2O4 ( $\mathrm{M}=\mathrm{Fe}, \mathrm{Co}, \mathrm{Mn})$ nanoparticles. J Am Chem Soc. 2004; 126: 273-9.
119. Liu K, Lan F, Jiang W, Zeng X, Hu H, Wu Y and Gu Z. Controllable preparation of ternary superparamagnetic nanoparticles dual-Doped with Mn and Zn elements. J Nanosci Nanotechno. 2012; 12: 8437-42

120. Wen X, Yang J, He B and Gu Z. Preparation of monodisperse magnetite nanoparticles under mild conditions. Curr Appl Phys. 2008; 8: 535-41.

121. Wen X and Zhongwei G. Preparation of monodispersed superparamagnetic magnetite nanoparticles. China: C.p bureau. 2007.

122. Yocum GT, Wilson LB, Ashari P, Jordan EK, Frank JA and Arbab AS. Effect of human stem cells labeled with ferumoxides-poly-L-lysine on hematologic and biochemical measurements in rats. Radiology. 2005; 235: $547-52$

123. Boussif O, Lezoualc'h F, Zanta MA, Mergny MD, Scherman D, Demeneix $\mathrm{B}$ and Behr JP. A versatile vector for gene and oligonucleotide transfer into cells in culture and in vivo: polyethylenimine. Proc Natl Acad Sci U S A. 1995; 92: 7297-301.

124. Liu G, Xie J, Zhang F, Wang Z, Luo K, Zhu L, Quan Q, Niu G, Lee S, Ai H and Chen X. N-Alkyl-PEI-Functionalized iron oxide nanoclusters for efficient siRNA delivery. Small. 2011; 7: 2742-9.

125. Mizrahy $S$ and Peer D. Polysaccharides as building blocks for nanotherapeutics. Chem Soc Rev. 2012; 41: 2623-40.

126. Tao T, Peng XF and Lee DJ. Fragmentation of wastewater sludge floc by planar ice front. J Colloid Interface Sci. 2005; 290: 298-301.

127. Reddy AM, Kwak BK, Shim HJ, Ahn C, Lee HS, Suh YJ and Park ES. In vivo In vivo Tracking of mesenchymal stem cells labeled with a novel chitosan-coated superparamagnetic iron oxide nanoparticles using 3.0T MRI. J Korean Med Sci. 2010; 25: 211-9.

128. Cheng LN, Duan XH, Zhong XM, Guo RM, Zhang F, Zhou CP and Shen J. Transplanted neural stem cells promote nerve regeneration in acute peripheral nerve traction injury: assessment using MRI. AJR Am J Roentgenol. 2011; 196: 1381-7.

129. Bhaskar U, Sterner E, Hickey AM, Onishi A, Zhang F, Dordick JS and Linhardt RJ. Engineering of routes to heparin and related polysaccharides. Appl Microbiol Biotechnol. 2012; 93: 1-16.

130. Wang YXJ, Quercy-Jouvet T, Wang HH, Li AW, Chak CP, Xuan S, Shi L, Wang DF, Lee SF, Leung PC, Lau CBS, Fung KP and Leung KCF. Efficacy and durability in direct labeling of mesenchymal stem cells using ultrasmall superparamagnetic iron oxide nanoparticles with organosilica, dextran, and PEG coatings. Materials. 2011; 4: 703-15.

131. Liao $\mathrm{MH}$ and Chen DH. Preparation and characterization of a novel magnetic nano-adsorbent. J Mater Chem. 2002; 12: 3654-9.

132. Nkansah MK, Thakral D and Shapiro EM. Magnetic poly(lactide-co-glycolide) and cellulose particles for MRI-based cell tracking. Magn Reson Med. 2011; 65: 1776-85.

133. Wilhelm $C$ and Gazeau F. Universal cell labelling with anionic magnetic nanoparticles. Biomaterials. 2008; 29: 3161-74

134. Zhang J, Zhu J, Bu X, Cushion M, Kinane TB, Avraham $\mathrm{H}$ and Koziel H. Cdc42 and RhoB activation are required for mannose receptor-mediated phagocytosis by human alveolar macrophages. Mol Biol Cell. 2005; 16: 824-34.

135. Zhang C, Wangler B, Morgenstern B, Zentgraf H, Eisenhut M, Untenecker H, Kruger R, Huss R, Seliger C, Semmler W and Kiessling F. Silica- and alkoxysilane-coated ultrasmall superparamagnetic iron oxide particles: a promising tool to label cells for magnetic resonance imaging. Langmuir. 2007; 23: 1427-34.

136. Park KS, Tae J, Choi B, Kim YS, Moon C, Kim SH, Lee HS, Kim J, Kim J, Park J, Lee JH, Lee JE, Joh JW, and Kim S. Characterization, in vitro cytotoxicity assessment, and in vivo visualization of multimodal, RITC-labeled, silica-coated magnetic nanoparticles for labeling human cord blood-derived mesenchymal stem cells. Nanomed-Nanotechno Biol and Med. 2010; 6: 263-76.

137. Liu HM, Wu SH, Lu CW, Yao M, Hsiao JK, Hung Y, Lin YS, Mou CY, Yang CS, Huang DM and Chen YC. Mesoporous silica nanoparticles improve magnetic labeling efficiency in human stem cells. Small. 2008; 4: 619-26.

138. Bernard AL, Guedeau-Boudeville MA, Marchi-Artzner V, Gulik-Krzywicki T, di Meglio JM and Jullien L. Shear-induced permeation and fusion of lipid vesicles. J Colloid Interface Sci. 2005; 287: 298-306.

139. Gilad AA, McMahon MT, Walczak P, Jr Winnard PT, Raman V, van Laarhoven HW, Skoglund CM, Bulte JW, andvan Zijl PC. Artificial reporter gene providing MRI contrast based on proton exchange. Nat Biotechnol. 2007; 25: 217-9.

140. Ly HQ, Frangioni JV and Hajjar RJ. Imaging in cardiac cell-based therapy: in vivo tracking of the biological fate of therapeutic cells. Nat Clin Pract Cardiovasc Med. 2008; 5 Suppl 2: S96-102.

141. Budde MD and Frank JA. Magnetic tagging of therapeutic cells for MRI. J Nucl Med. 2009; 50: 171-4. 